\title{
THE EFFECT OF FIRM-SPECIFIC FACTORS ON THE MARKET REACTION TO DIVIDEND CHANGE ANNOUNCEMENTS: NEW EVIDENCE FROM EUROPE
}

\author{
Elisabete Vieira \\ Instituto Superior de Contabilidade e Administração \\ Universidade de Aveiro \\ Management Department \\ Rua Associação H. B. Voluntários \\ 3811-953 Aveiro \\ Portugal \\ Tel: 351234380110 \\ Fax: 351234380111 \\ elisabete.vieira@isca.ua.pt
}

\section{Clara Raposo}

ISCTE

Business School

Av. Prof. Aníbal de Bettencourt

1600-189 Lisboa

Portugal

Tel: 351217958607

Fax: 351217958605

clara.raposo@iscte.pt 


\title{
THE EFFECT OF FIRM-SPECIFIC FACTORS ON THE MARKET REACTION TO DIVIDEND CHANGE ANNOUNCEMENTS: NEW EVIDENCE FROM EUROPE
}

\begin{abstract}
The dividend policy is one of the most debated topics in the finance literature. According to the dividend signalling hypothesis, which has motivated a significant amount of theoretical and empirical research, dividend change announcements trigger share returns because they convey information about management's assessment on firms' future prospects. Consequently, a dividend increase (decrease) should be followed by an improvement (reduction) in a firm's value.

However, some studies have not supported the hypothesis of a positive relationship between dividend change announcements, and the subsequent share price reaction, such as the ones of Lang and Litzenberger (1989), Benartzi, Michaely and Thaler (1997), Chen, Firth and Gao (2002), Abeyratna and Power (2002) and Vieira (2005). Furthermore, some authors found evidence of a significant percentage of cases where share prices reactions are opposite to the dividend changes direction, like the works of Asquith and Mullins (1983), Benesh, Keown and Pinkerton (1984), Born, Mozer and Officer (1988), Dhillon and Johnson (1994) Healy, Hathorn and Kirch (1997), and, more recently, Vieira (2005).

Consequently, we try to identify firm-specific factors that contribute in explaining the adverse market reaction to dividend change announcements. Globally, our evidence suggests that only for the UK sample we have firm-specific factors influencing the market reaction to dividend change announcements. We conclude that the UK firms with a negative market reaction to dividend increase announcements have, on average, higher size, lower earnings growth rate and lower debt to equity ratios.
\end{abstract}

Key Words: Cash Dividends, Signalling Hypothesis, Firm-Specific Factors

JEL Classification: G35, G32 


\section{INTRODUCTION}

One of the most important assumptions of the signalling hypothesis is that dividend change announcements are positively correlated with share price reactions and future changes in earnings.

There have been a significant number of empirical tests showing that dividend change announcements are positively associated with share returns in the days surrounding the dividend change announcement. Pettit $(1972,1976)$ found strong support that dividend change announcements convey information to the market. Similar results were obtained by several authors, such as by Aharony and Swary (1980), Benesh, Keown and Pinkerton (1984) and Dhillon and Johnson (1994) for dividend change announcements, Asquith and Mullins (1983) for dividend initiations, Lee and Ryan (2000, 2002) for dividend initiations and omissions and Lippert, Nixon and Pilotte (2000) for dividend increase announcements. Although all these studies were carried out on the American market, Travlos, Trigeorgis and Vafaes (2001) analysed the market of Cyprus, Gurgul, Madjosz and Mestel (2003), the Austrian market, and Yilmaz and Gulay (2006), the Turkey market, finding also support for the dividend information content hypothesis.

Although there are empirical evidence supporting the positive relationship between dividend change announcements and the subsequent share price reactions, some studies have not supported this idea. Studies done by Lang and Litzenberger (1989) and Benartzi, Michaely and Thaler (1997) for the American market, Conroy, Eades and Harris (2000) for the Japanese market, Chen, Firth and Gao (2002) for the Chinese market and Abeyratna and Power (2002), for the United Kingdom, Vieira (2005), for two of the three markets analysed (Portugal and France) and Hossain, Siddiquee and Rahman (2006) for the Bangladesh market find no evidence of a significant relationship between dividend announcements and share returns.

Furthermore, several studies found evidence of a significant percentage of cases where share prices reactions are opposite to the dividend changes direction, like the works of Asquith and Mullins (1983), Benesh, Keown and Pinkerton (1984), Born, Mozer and Officer (1988), Dhillon and Johnson (1994) Healy, Hathorn and Kirch (1997), and, more recently, Vieira (2005). 
In this context, we will try to analyse whether market reaction to dividend change announcements is associated with firm-specific factors. To do so, we will relate the firm specific factors to the market share price reaction around the dividend change announcements date to evaluate whether the firm-specific factors can influence the market reaction in the dividend announcement period.

Several authors have documented a relationship between market share price reaction to dividend change announcements and firm-specific factors, such as Asquith and Mullins (1983), Ghosh and Woolridge (1988), Eddy and Seifert (1988), Haw and Kim (1991), Mitra and Owers (1995) and Healy, Hathorn and Kirch (1997).

Asquith and Mullins (1983) found that market reaction to dividend announcements depends on the magnitude of the dividend payment. Ghosh and Woolridge (1988) concluded that, for firms that omit or cut dividends, the most significant firm specific factors that influence this relationship are the percentage change in dividend, the firms' size, the share performance before the announcement date and the negative information released before the dividend change. Eddy and Seifert (1988) and Haw and Kim (1991) found a negative relation between firm size and abnormal returns for firms that increase dividends and Mitra and Owers (1995) found a similar relation for firms that initiate dividends. These results are consistent with Miller and Rock's (1985) position that the dividend announcement effect varies across firms with different degrees of information asymmetry. Healy, Hathorn and Kirch (1997) results suggested that firms whose capital market have reacted negatively to an initial dividend announcement documents lower dividend yield ratio and PER than firms whose reaction was positive and higher debt/equity ratio, current ratio and growth earnings before the announcement period.

Globally, our evidence suggests that only for the UK sample we have firm-specific factors influencing the market reaction to dividend change announcements. We conclude that the UK firms with a negative market reaction to dividend increase announcements have, on average, higher size, lower earnings growth rate and lower debt to equity ratios.

The remainder of this paper is organised as follows. Section 2 presents the hypothesis. The sample selection and empirical methodology are described in Section 3. Section 4 discusses the empirical results and section 5 provides the conclusion. 


\section{HYPOTHESIS}

We formulate a hypothesis with the purpose of analysing if there are firm-specific factors that influence the market reaction around dividend change announcements. This prediction can be tested by the following alternative hypothesis:

$H_{1}$ : "Firm-specific factors affect the market reaction around the dividend change announcements date”

If we find firm-specific variables significantly associated with price changes in the dividend announcement period, such as firm size, firm growth and financial leverage, we will have evidence of firm-specific factors influencing the market reaction to dividend announcements, and, potentially, find some reasons for a negative relationship between dividends and share price movements in the announcement period.

\section{SAMPLE SELECTION AND METHODOLOGY}

In this section, we will identify which data we must collect as well as the methodology to be used in order to test the formulated hypotheses.

\section{SAMPLE SELECTION}

We based this study in the sample of a previous study done recently [Vieira (2005)]. Our purpose is to continue to analyse the three European markets considered in previous studies, so we continue to explore the UK, the French and the Portuguese markets. The sample is drawn from dividend change announcements of firms listed on the Euronext Lisbon (EL), Euronext Paris (EP) and London Stock Exchange (LSE). We obtain the data on Bloomberg and Datastream databases and, in addition, for the Portuguese sample, the Dhatis database.

Table 1 reports the number of dividend change announcement events (dividend increases and dividend decreases) for the three samples. The Portuguese sample contains 279 events: 158 increases and 121 decreases. The French sample has 297 events: 235 increases and 62 decreases and finally, the UK sample consist of 2,889 events: 2,623 increases and 266 decreases. 
The preponderance of dividend increases over decreases in the three samples is consistent with prior results that firms are reluctant to cut dividends. However, we would like to emphasise, for the Portuguese sample, the significant number of dividend decreases (about $43 \%$ of sample events), when compared with the French and, specially, with the UK sample, as well as the major number of empirical works in this domain. Portuguese percentages are similar to the ones of some emergent markets, such as Thailand and Korea [Aivazian, Booth and Cleary (2003b)] and the French and the UK percentage of dividend changes, especially the case of the UK sample, are similar to the ones of Abeyratna and Power (2002) ${ }^{1}$.

The UK firms usually announce both dividends and earnings simultaneously. Therefore, the UK sample is divided into six categories, according to the scheme presented below:

\begin{tabular}{lcccc}
\hline \multirow{2}{*}{ Announcement Type } & \multicolumn{3}{c}{ Dividends } \\
\cline { 3 - 5 } & Increases & No-changes & Decreases \\
\hline \multirow{2}{*}{ Earnings } & Increases & DIEI & DNCEI & DDEI \\
& Decreases & DIED & DNCED & DDED \\
\hline
\end{tabular}

Type of events for the UK, according the relation between dividends and earnings

Thus, there are the following events: dividend increase-earnings increase (DIEI), dividend increase-earnings decrease (DIED), dividend no-change-earnings increase (DNCEI), dividend no-change-earnings decrease (DNCED), dividend decrease-earnings increase (DDEI), and dividend decrease-earnings decrease (DDED).

\section{METHODOLOGY}

Our samples are an unbalanced panel data. Employing the panel data methodology, we use the three common techniques for estimating models with panel data, which are the pooled ordinary least squares (OLS), the fixed effects model (FEM), and the random effects model (REM). Subsequently, we will use an F-statistic and the Hausman (1978) test to choose the most appropriate model for our samples. We present the standard errors corrected for heteroscedasticity and covariance, based on the White's (1980) heteroscedasticity consistent standard errors method.

The hypothesis formulated in the previous section is associated with the analysis of firm-specific factors that can affect the market share price reaction surrounding

\footnotetext{
${ }^{1}$ One possible explanation for these sample statistics may be the exposure of emerging and Portuguese markets to more economic risks.
} 
dividend change announcements. The dividend information content hypothesis states that through dividend change announcements investors receive a signal concerning management's assessment of the firm's future prosperity. The intensity of the market reaction to any dividend announcement depends on the amount of new information, it contains for the investor.

Several authors through the years have documented the relationship between the valuation effect of dividend changes and firm-specific variables, such as Asquith and Mullins (1983), Eddy and Seifert (1988), Haw and Kim (1991), Mitra and Owers (1995) and Hathorn and Kirch (1997). Some authors found a negative relationship between firm size and abnormal returns around the dividend announcement date [Eddy and Seifert (1988), Haw and Kim (1991) and Mitra and Owers (1995), among others]. Ghosh and Woolridge (1988) concluded that the most significant factors are the percentage change of dividends, the firm's size and the share performance before the announcement date. In addition, Healy, Hathorn and Kirch (1997) suggest that a firm's dividend yield, PER, debt/equity ratio and current ratio have an effect on the probability that the capital market will react negatively to an initial dividend announcement, which can be important to explain the inverse relation between dividend change announcements and the market reaction.

In selecting the specific factors to study, we were guided by information-oriented variables which include proxies to measure the information content of dividend change announcements, trying to identify the factors that contribute significantly to the market reaction to dividend announcements. The factors are the firm size, the percentage change in dividends, the earnings growth, the market to book ratio, the price/earnings ratio and the debt/equity ratio.

We regard as the "buy-and-hold" abnormal return (BHAR) to measure the market reaction to dividend change announcements. The BHAR for share i from time $a$ to $b$ $\left[\mathrm{BHAR}_{\mathrm{i}(\mathrm{a} \text { to b)}]}\right.$ takes the following form:

$$
B H A R_{i(a \text { to } b)}=\prod_{t=a}^{b}\left(1+R_{i, t}\right)-\prod_{t=a}^{b}\left(1+R_{m, t}\right)
$$

The time period $a$ to $b$ constitutes three trading days from $\mathrm{t}=-1,0+1$.

We start by testing the relation between the market reaction to a dividend change announcement (in the event period) and the firm specific factors that we suppose can 
influence this relation, estimating the following regression, based on Ghosh and Woolridge (1988):

$$
\left|B H A R_{i,-1 \text { to }+1}\right|=\alpha+\beta_{1} F S_{i}+\beta_{2}\left|P C D_{i}\right|+\beta_{3}\left|E G_{i}\right|+\beta_{4} M B_{i}+\beta_{5} P E R_{i}+\beta_{6} D E_{i}+\varepsilon_{i, t}
$$

where:

$$
\begin{aligned}
& \mathrm{FS}_{\mathrm{i}}=\text { firm size for share } \mathrm{i} \text {, computed as the natural log of market value of } \\
& \mathrm{PCD}_{\mathrm{i}}=\text { percentage change of dividends for share } \mathrm{i} \text {, computed as the annual }
\end{aligned}
$$

Interpretation of the signs of some variables will differ depending on the dividend changes direction. To overcome the problem of interpreting the coefficient signal depending on the direction of dividend changes, and consistent with Haw and Kim (1991), we consider the absolute term of such variables. All financial variables are measured at the end of the firm's fiscal year immediately prior to the dividend announcement.

The independent variables are explained bellow:

\section{Firm Size (FS)}

Firm size is associated with information asymmetry, since less information is available to the market about smaller firms, which attract less institutional interest and, as a result, are subject to less scrutiny by financial analysts. In addition, they receive less coverage in the financial press. To the extent that informational asymmetry is greater for small firms than for large firms [Haw and Kim (1991)], the information content of dividend announcements will be greater for small firms. Smaller firms have less information available in the market, so, when they announce dividend changes, it generates greater market surprises that induce a larger reaction by the market. Therefore, we expect this 
coefficient to have a negative signal. We use market capitalization as a surrogate for firm size. FS is defined as the natural $\log ^{2}$ of market value of common equity at the end of the year before the dividend change year.

\section{Percentage Change in Dividends (PCD)}

Following Asquith and Mullins (1983), we consider the percentage change of dividends as a proxy for the information content of dividend changes. PCD is defined as the change in dividends divided by the share price in the announcement day. To overcome the problem of interpreting the coefficient signal depending on the direction of dividend changes, and consistent with Haw and Kim (1991) approach, we will consider the absolute term of this variable. Assuming that a bigger change reveals more information, the coefficient of this variable is expected to be positive.

\section{Earnings Growth (EG)}

Prior earnings are examined to test whether their growth magnitude is a predictor of the market reaction to dividend change announcements. EG is computed as the average earnings growth rate based on the year prior to the dividend change year ${ }^{3}$. For the same reasons pointed out in the last factor, we will consider the absolute term of this variable. It is expected a positive relation between earnings growth and the market reaction to dividend change announcements.

\section{Market to Book Ratio (MB)}

For a proxy to Tobin's Q, we consider the market to book ratio as an indication of investors' expectation of a firm's growth prospects or investment opportunities, and thus as a proxy for firm maturity and for firms' growth opportunities. MB is calculated by dividing the market price per share at the dividend change announcement date by the book value per share at the end of the year before the dividend change year. A high ratio value means that a firm has strong growth prospects. Firms with fewer investment opportunities will have more free cash flows and so can pay higher dividends. The

\footnotetext{
${ }^{2}$ We use the logarithm of market value because it would better conform to the characteristics of symmetry and normality.

${ }^{3}$ Special care will be taken when calculating percentage changes involving a negative value of earnings to ensure that any change in sign did not give a false picture of any deterioration or improvement in earnings.
} 
market reaction to a dividend increase must be higher for firms with fewer investment opportunities, so the coefficient of this variable is expected to be negative.

\section{Price/Earnings Ratio (PER)}

PER is computed as the price per share divided by the earnings per share. A high PER may result from high price or low earnings. Thus, it may mean that investors believe the firm has growth opportunities and/or its earnings and cash flows are relatively safe. For firms that increase their dividends, it may also signal that they have less growth prospects than expected and thus dividend increases may be a negative signal, causing the market to review its perceptions downward. Therefore, we cannot determine, a priori, the direction of the relation between this ratio and the market reaction to dividend change announcements.

\section{Debt/Equity Ratio (DE)}

Debt to equity ratio is used as a proxy for firms' financial risk. DE is computed as the book value of total debt (book value of total long term and short term debt) divided by the total book value of equity at the end of the year prior to the dividend change announcement. Assuming the reluctance of managers to decrease dividends [Lintner (1956)], the higher the financial risk, the lower the probability that a firm increase dividends if managers are unsure about their capacity to continue paying dividends. Therefore, the market will react strongly to a dividend change announcement for firms with higher DE ratios. As a result, we expect this coefficient to have a positive signal.

Schematically, we present below the variables, abbreviations and the expected signs of the regression coefficients:

\begin{tabular}{lcc}
\hline \multicolumn{1}{c}{ Variables } & Abbreviations & Expected sign \\
\hline Firm Size & FS & - \\
Percentage Change in Dividends (absolute terms) & PCD & + \\
Earnings Growth (absolute terms) & EG & + \\
Market to Book Ratio & MB & - \\
Price/Earnings Ratio & PER & $?$ \\
Debt/Equity Ratio & DE & + \\
\hline Independent variables, abbreviations, and the expected signal of the regression coefficients
\end{tabular}

To see if the proxies are highly correlated and, in effect, proxying for one another, we will analyse the correlation between the independent variables. 
Following, we wish to look at the contribution of the firm specific variables in explaining the market reaction to dividend change announcements, but identifying the different types of events, looking separately for dividend increase announcements and dividend decrease announcements.

For the Portuguese and the French samples, the regression can be expressed as:

$$
\begin{aligned}
& \left|B H A R_{i,-1 \text { to }+1}\right|=\alpha+\beta_{1 A} \text { DI } \times F S_{i}+\beta_{1 B} \mathrm{DD} F_{i}+\beta_{2 A} \mathrm{DIx}\left|P C D_{i}\right|+ \\
& +\beta_{2 B} \mathrm{DDx}\left|P C D_{i}\right|+\beta_{3 A} \mathrm{DIx}\left|E G_{i}\right|+\beta_{3 B} \mathrm{DDx}\left|E G_{i}\right|+ \\
& +\beta_{4 A} \mathrm{DI} \times M B_{i}+\beta_{4 B} \mathrm{DD} \times M B_{i}+\beta_{5 A} \mathrm{DI} \times \mathrm{PER}_{i}+ \\
& +\beta_{5 B} \mathrm{DD} \times \mathrm{PER}_{i}+\beta_{6 \mathrm{~A}} \mathrm{DI} \times E_{i}+\beta_{6 B} \mathrm{DD} \times D E_{i}+\varepsilon_{i, t}
\end{aligned}
$$

For the UK market we need to consider more dummy variables in order to identify the relation between dividend and earnings announcements. Thus, we will have a total of twenty four explanatory variables, i.e., six independent variables times four. The regression can be expressed in the following manner:

$$
\begin{aligned}
\left|B H A R_{i,-1 \mathrm{to}+1}\right|= & \alpha+\beta_{1} \Phi \times F S_{i}+\beta_{2} \Phi \times\left|P C D_{i}\right|+\beta_{3} \Phi \times\left|E G_{i}\right|+ \\
& +\beta_{4} \Phi \times M B_{i}+\beta_{5} \Phi \times P E R_{i}+\beta_{6} \Phi \times D E_{i}+\varepsilon_{i, t}
\end{aligned}
$$

where $\Phi$ is the vector of coefficients for the dummy variables relating the dividend and earnings changes, set equal to 1 respectively, if (a) both dividend and earnings increases; (b) dividend increases and earnings decreases; (c) dividend decreases and earnings increases; (d) both dividend and earnings decreases, and 0 otherwise.

Afterwards, we will run a logistic regression to analyse the relation between the probability of a negative (positive) market reaction to dividend increase (decrease) announcements and the firm-specific characteristics.

For the dividend increase events, we express the regression as:

$$
\text { BHARI }_{l,-1 \mathrm{to}+1}=\alpha+\beta_{1} F S_{i}+\beta_{2} \mathrm{LPCD}_{1}+\beta_{3} \mathrm{LEG}_{\mathrm{i}}+\beta_{4} L M B_{1}+\beta_{5} L P E R_{1}+\beta_{6} L D E_{i}+\varepsilon_{t}
$$

where:

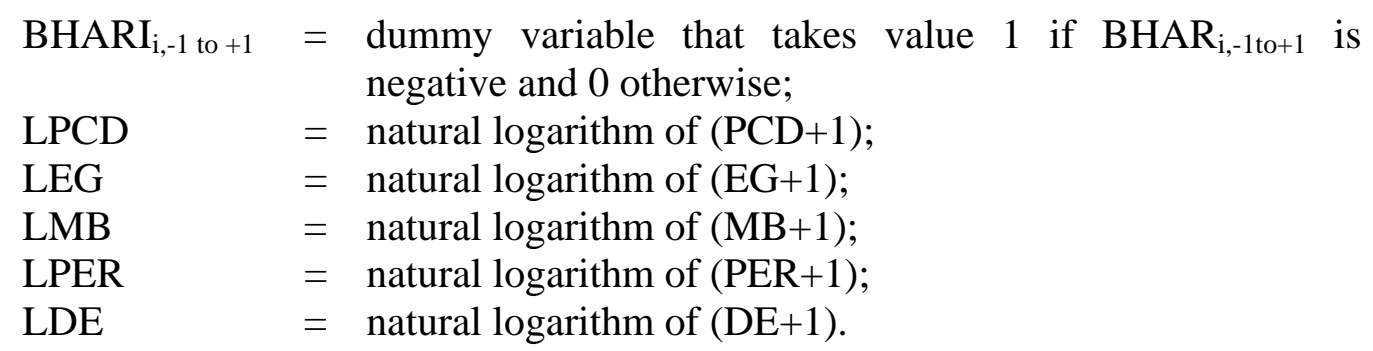

For the dividend decrease events, we express the regression in the subsequent manner: 


$$
\text { BHARD }_{l,-1 \mathrm{to}+1}=\alpha+\beta_{1} F S_{i}+\beta_{2} \mathrm{LPCD}_{1}+\beta_{3} \mathrm{LEG}_{\mathrm{i}}+\beta_{4} L M B_{1}+\beta_{5} L P E R_{+}+\beta_{6} L D E_{\mathrm{i}}+\varepsilon_{t}
$$

where $\mathrm{BHARD}_{\mathrm{i},-1 \text { to }+1}$ is a dummy variable that takes value 1 if $\mathrm{BHAR}_{\mathrm{i},-1 \mathrm{to}^{+1}}$ is positive and 0 otherwise.

Finally, we will analyse the firm characteristics according to the market reaction to dividend change announcements. Thus, we will consider the sub-samples defined previously. Specifically, we wish to study whether specific factors can be distinguished between the dividend increase events with a positive market reaction (PRDI) and a negative market reaction (NRDI) and between the dividend decrease events with a negative market reaction (NRDD) and a positive reaction (PRDD).

\section{EMPIRICAL RESULTS}

To evaluate whether firm-specific factors affect the market reaction in the dividend announcement period, we test the relationship between the BHAR -1 to +1 and the firmspecific variables, estimating the regression [2]. Results are shown in Table 2.

We start by estimating the Pearson correlations among the independent variables. Panel A of Table 2 presents the correlation matrix among the exogenous variables along with the statistical significance. We are expecting higher values for the correlation between MB ratio and PER. Indeed, for both the Portuguese and French samples, the higher correlation coefficient is between the PER and the market to book ratio, but still below $50 \%$ in the former sample and below $40 \%$ in the latter. Consequently, we can conclude that these two variables are not proxying for one another. In the UK sample, the highest correlation coefficient is between the market to book ratio and the debt to equity ratio, exhibiting a value of $40.2 \%$. In general, although we have some significant correlations, the coefficients are not very high (always bellow 50\%), so it does not appear to be sufficiently large to cause concern about multicollinearity problems.

The pooled OLS, the FEM and the REM estimation results of regression [2] for all the dividend change events (dividend increases and decreases) are reported in Panel B. The best model is chosen according to the F statistic and the Hausman test, and is presented in bold. For all the three samples the best model is the REM. 
Portuguese results show that, with the exception of the coefficient for the firm size, all the other sample coefficients present the expected signal. However, all of them are statistically insignificant. Consequently, we find no variables showing statistical significance in explaining the cumulative abnormal returns on the dividend announcement period.

Regarding the French sample, and looking for the REM results, we can see that all the variables have the predicted sign except for the firm size and the earnings growth rate. However, they are both statistically insignificant. Only one firm specific factor contributes in explaining the market reaction to dividend changes, which is the DE ratio. However, it is only statistically significant at the $10 \%$ level.

In contrast with prior studies [Haw and Kim (1991), Ghosh and Woolridge (1988) and Mitra and Owers (1995)], we did not find a significant relationship between firm size and the cumulative abnormal returns for both the Portuguese and the French markets. This can probably be explained by the similar size of Portuguese and French firms that constitute the sample.

Finally, the UK results exhibit for all the coefficients the predicted sign except for the MB ratio, but its value is not statistically different from zero. Two out of the six independent variables contribute in explaining the market return in the 3 days surrounding the dividend change announcements. The significant variables are the EG rate and the PER. This last coefficient, whose signal we could not predict in advance, is negative, implying that higher PER values are associated with a smaller market reaction do dividend changes. The EG rate appears to be the most powerful explanatory variable between the two. It suggests that investors have different expectations as to dividend announcements depending on a firm's prior history of earnings growth [Healy, Hathorn and Kirch (1997)].

Our global results show that, considering all the dividend change events, the only market where we have firm specific variables with power to explain the market abnormal returns in the announcement period is the UK. The explanatory variables that contribute in explaining the BHAR in the 3 days surrounding the dividend change announcements are the EG and the PER. The reason behind failing to document the predicted sign in some coefficients could be an indication that it is associated with the 
opposite relation between dividend change announcements and the subsequent market reaction, found by Vieira (2005), with the same samples.

Afterwards, we are interested in exploring the power of these variables in explaining the market reaction to the different dividend change events. Hence, we include dummy variables in the preceding regression to identify dividend increases and decreases.

The pooled OLS, the FEM and the REM estimation results obtained when we run the regression [3] to determine the contribution of the firm specific variables in explaining the market reaction to dividend change announcements, with dummies to identify the different types of events, are reported in Table 3. The best model is chosen according to the F statistic and the Hausman test. Once again, the best model for all the samples is the REM.

Looking for the Portuguese REM results, we can see that the coefficient on market to book value is positive for the dividend increase events, contrary to the expected sign, and negative for the dividend decrease events, which could suggest a possible reason for dividend increase events associated with a negative market reaction. However, those coefficients, like all the others, are statistically insignificant. Consequently, we conclude that, for the Portuguese sample, none of the firm specific variables contribute to explain the market reaction in each of the two distinct groups of events.

Regarding the French sample, the results show that, although some explanatory variables have different signs for the dividend increase and dividend decrease events, none of the coefficients are statistically different from zero. For the French market, we conclude, like in the Portuguese sample, that none of the firm specific variables contribute to explaining the market reaction in each of the two distinct groups of events.

The UK results show that the coefficients on the DE ratio have different signs in the different groups of events. However, none of those coefficients is statistically significant. Six out of the twenty four explanatory coefficients are statistically significant. The variables that contribute to explain the dependent variable are the PCD for the DIEI events, the earnings growth for the DIEI, DIED and DDED events, the MB ratio for the DIED events and finally, the PER for the DIED events. However, the MB ratio does not have the predicted sign.

Regarding the percentage change of dividends, the result suggests that the higher the dividend increases, when the earnings also increase, the higher the market reaction. This 
evidence appears to be consistent with the dividend signalling hypothesis and is in agreement with the results of Eddy and Seifert (1992). The fact that this coefficient is positive and statistically significant for the DIEI events, and negative for the DIED events, although not statistically significant, suggests evidence of our previous conclusion that earnings announcements convey information beyond what is revealed by dividend change announcements.

All the significant coefficients on earnings growth rate are positive, according to the expected sign. Earnings growth effects are less significant in the dividend decreases case than in the dividend increases case.

Contrary to the expected sign, the coefficient on MB is positive for the dividend increases, but only statistically significant for the DIED events. It suggests that investors do not interpret this relation according to the assumptions of the free cash flow hypothesis [Jensen (1986)]; otherwise the coefficient will be negative. On the other side, this could be an indication that dividend increases that are preceded by high MB ratios convey good future prospects, and so, the market reacts positively, suggesting some evidence of the dividends signalling hypothesis. Because of the independency between firms and shareholders, the investors can privilege the dividend increase announcements over other type of information, such as the MB ratio. In fact, on this market we find some evidence, although weak, of the dividend information content hypothesis.

Finally, the coefficient on PER, for which we have not predicted, a priori, a specific sign, is negative. This result suggests that, when a dividend increase is preceded by a high PER, investors might interpret it as an indication that firms have less growth prospects than expected, and reacts accordingly, revising its perceptions downward.

Our results considering the dividend increase and dividend decrease events separately are quite similar to the ones obtained without distinguishing the two types of events. The only market where we have firm specific variables with power to explain the market abnormal returns in the announcement period is the UK. The explanatory variables that contribute in explaining the BHAR in the 3 days surrounding the dividend change announcements are the earnings growth, and, only for dividend increase events, the percentage change of dividends, the MB ratio and the PER. The reason behind the evidence of some different signs for the distinct types of events (dividend increases and 
decreases) on the same firm-specific variable could be an indication that it is associated with the opposite relation between dividend change announcements and the subsequent market reaction.

\section{Robustness}

To evaluate the robustness of the results, we repeated the analysis using alternative explanatory variables, reflecting other firm-specific factors ${ }^{4}$.

Fist, we include an additional liquidity variable that measures the adequacy of a firm's cash resources to meet its near-term cash obligations, the working capital ratio (WCR), computed as total current assets divided by total current liabilities at the end of year before the announcement period. Running the several regressions, the results show that the coefficient on WCR is always statistically insignificant, not contributing in explaining the market reaction surrounding dividend change announcements.

In addition, we include a variable to measure the financial constraints. A commonly used index to measure financial constraints is the $\mathrm{KZ}$ index, as it was denominated by Lamont et al. (2001). The index constructed by these authors uses the coefficients of the regression of Kaplan and Zingales (1997) work. As this index is composed by five variables and we have already used some of them in the regression [2], we will adopt the cash flow to assets ${ }^{5}$ measure $(\mathrm{CF})$ as a proxy for the financial constraints, which is also popular in the empirical tests done in this domain, computed as operating income before depreciation minus interest expense, income taxes and preferred stock dividends scaled by the total assets at the end of the year before the dividend announcement, as previously defined. The results show that the coefficient on CF is statistically insignificant for all the three countries, not contributing in explaining the market reaction surrounding dividend change announcements ${ }^{6}$.

As these two variables do not change our conclusions, we decide to not consider these additional firm-specific variables in the following analysis.

\footnotetext{
${ }^{4}$ For simplicity reasons, the results are not reported in the study, but available from authors upon request.

${ }^{5}$ The other four variables of the KZ index are: the market to book ratio, debt to total capital, dividends to total capital and cash holdings to capital.

${ }^{6}$ Globally, the increases in the adjusted $\mathrm{R}^{2}$ when we introduce the CF variable are worthless.
} 
The next step consists of analysing the relation between the probability of a negative (positive) market reaction to dividend increase (decrease) announcements and the firmspecific characteristics.

Table 4 presents the results of the logistic regression [4] for dividend increase events (Panel A) and for dividend decrease events (Panel B).

Panel A presents the regression results of the relation between the probability of a negative market reaction to dividend increase announcements and firm specific characteristics. The factors that, in global terns, contribute to a negative market reaction are the $\mathrm{FS}$, the $\mathrm{EG}$, the $\mathrm{MB}$ ratio and the $\mathrm{DE}$ ratio.

The results of the Portuguese sample exhibit two coefficients statistically significant and negative, which are the logarithm of earnings growth (LEG) and the logarithm of debt to equity ratio (LDE). The French results present one negative and marginally significant coefficient, at the $10 \%$ level, which is the logarithm of market to book ratio (LMB). The UK sample presents three out of the six variables as statistically significant. The LDE is negative and the firm size (FS) and the LMB are positive. This last one was negative in the French sample.

The evidence that in the UK the coefficient on FS is positive and statistically significant suggests that firms with higher size have a higher probability of a negative market reaction. One possible reason might be the fact that the information asymmetry is smaller for bigger firms, as they have more information available in the market and are subject to more scrutiny by financial analysts. Consequently, the investors of bigger firms have more information, beyond that of dividend changes, to assess and thus, to react. This result appears to be consistent with the evidence obtained by Haw and Kim (1991), Eddy and Seifert (1992) and Mitra and Owners (1995).

The fact that the coefficient on earnings growth rate is negative suggests that the higher the earnings growth, the less the probability that the market will react negatively to a dividend increase announcement. Since earnings growth are a primary source of information regarding future dividends [Lintner (1956) and Vieira (2005), among other authors], it is possible that the prior earnings growth may be a predictor of the market reaction at the announcement period.

The LMB ratio is negative and significant in France, which is a signal that the higher the $\mathrm{MB}$ ratio, the less the probability that the market reacts negatively to dividend 
increases. In the UK market, the opposite happens. The coefficient is positive and significant, suggesting that a high $\mathrm{MB}$ ratio increases the likelihood that the market reacts negatively to dividend increases. The different reaction in the two countries might be related to the way shareholders interpret the information, and to the firm characteristics. The result of UK sample suggests that the market has a higher probability to react negatively to dividend increases if firms have growth opportunities. This seems to be in contrast with the previous results (Table 3) and in accordance with the free cash flow hypothesis. The French result suggests that the market reacts mainly and positively to dividend increases. This could imply that investors believe that high MB firms that increase dividends are signalling continuing growth opportunities, which is in accordance with the dividend signalling hypothesis. Another possible reason for that to happen can be associated with the firm's stage. Perhaps French firms are, generally, in the maturity stage and MB is high, not because of a high market value of equity, but because of an obsolete book value.

LDE is negative and significant in two out of the three countries (Portugal and the UK), suggesting that a high debt to equity ratio decreases the likelihood that the market reacts negatively to a dividend increase announcement. This evidence does not suggest that markets react negatively when firm's debt is high because of the greater risk of covenant, like the results of Healy, Hathorn and Kirch (1997), but instead suggests, according the opinion of Ross (1977), that good quality firms are able to differentiate themselves from lesser quality firms by assuming a higher leverage ratio. Investors can interpret this as a signal that managers are sure about their capacity to continue paying dividends. This evidence can be an indication that leverage and dividends are complementary signalling mechanisms.

In sum, firms with negative market reactions to dividend increase announcements have, on average, higher size, lower earnings growth rate and lower debt to equity ratios. These results suggest that, for bigger firms under low earnings growth rate and low DE ratio, the market interprets a dividend increase as a negative signal.

Panel B presents the regression results of the relation between the probability of a positive market reaction to dividend decrease announcements and firm specific characteristics. The only factor that contributes significantly to a positive market reaction is the PER, and only for the French market. It is negative and statistically 
significant at the 5\% level. The Portuguese and the UK samples exhibit no coefficients statistically significant.

The fact that PER is negative means that it contributes to a lower probability that the market reacts positively to a dividend decrease. This could imply that investors believe that high PER firms that decrease dividends are conveying to the market information that they have less growth prospects than expected.

Summarising, firms with positive market reactions to dividend decrease announcements tend to have, on average, lower PER, but only for the case of the French market. This suggests that under a low PER, the French market interprets a dividend decrease as a positive signal. For the other two samples, our results do not find support for a relationship between firm specific characteristics and the probability of a positive market reaction to dividend decrease announcements.

Finally, we wish to analyse the differences in firm characteristics between the distinct market reaction (positive or negative) to dividend increase and dividend decrease announcements in order to see if there are any systematic differences between events with a positive and a negative market reaction for each of the two types of events.

Table 5 presents the mean values for the selected specific factors and the t-statistic test for the differences between the means of the two groups (PRDI versus NRDI and NRDD versus PRDD events).

Looking for the mean differences between the dividend increase events with a positive market reaction and those with a negative reaction, we can see that there are significant differences between the means of the firm size for the UK, the means of the percentage change of dividends for the UK, the means of earnings growth for Portugal and the UK, the means of MB ratio for the French and the UK markets, the means of the PER for the UK and, finally, the means of the DE ratio for the Portuguese sample.

We use firm size as a proxy for the information asymmetry. Consistent with the signalling hypothesis, we expect that smaller firms, which are likely to experience greater information asymmetry, tend to use dividends to signal firm's future prospects, and that the market consider this information as worthy and reacts positively to dividend increases. Therefore, we expect for firms with a direct relation between dividend increases and the market reaction having a smaller size than those with an inverse relation between the two variables. Thus, consistent with the assumptions of the 
signalling hypothesis, we expect to have lower values for the first group compared to the second one. Indeed, for the UK sample, the only one where the mean difference is significant, we have a lower firm size mean value for the first group. Consistent with the signalling hypothesis, we find that smaller firms in the UK market, which are likely to experience greater information asymmetry, tend to use dividends as a signal mechanism. This evidence is consistent with Miller and Rock's (1985) position that the dividend announcement effect varies across firms with different degrees of information asymmetry.

Assuming that a bigger change of dividends reveals more information, we expect to find higher mean values for the group with a direct relation between dividend changes and market reaction. According to what is expected, we find significant higher mean values for the percentage change of dividends in the events characterised by a direct relation between dividend increases and the market reaction for the UK sample. Although it also happens in the Portuguese sample, the mean difference is not significant. This is an indication of the market reaction being a function of how much information is revealed.

Past earnings growth can be associated with expectations of future earnings growth. Thus, assuming dividend increase announcements convey good information about future earnings prospects, we expect to have higher earnings growth mean values for the first group compared to the second one. As we can see, this happens for all the three samples, but the difference is only significant for the Portuguese and the UK samples.

The market to book ratio can be considered as a proxy for the firms' growth opportunities. A high ratio can be a signal that a firm has strong growth prospects. According to the free cash flow assumptions, firms with fewer investment opportunities will have more free cash flows and so can pay higher dividends. Hence, we expect to have higher mean values for the MB ratio in the NRDI events than in the PRDI events, reflecting a negative reaction to earnings distributed that must be retained to finance the future growth prospects. In fact, it happens in the UK market. The results are consistent with the ones obtained in Table 4 (Panel A), where we conclude that a high MB ratio increases the likelihood that the market reacts negatively to dividend increases. On the other hand, according to the dividend signalling hypothesis, we can interpret a high MB ratio as conveying optimistic information to the market about firm's future earnings prospects as a sequence of growth opportunities and, consequently, firms with a positive market reaction to dividend increase announcements will have higher values for the MB 
ratio. Indeed, this situation happens in the French market. This result is also consistent with the evidence of Table 4 (Panel A) for this sample, where we find evidence that the higher the MB ratio, the less the probability that the market reacts negatively to dividend increases.

The PER mean value is significantly lower (higher) for the events with a positive (negative) market reaction in the UK sample. This result is in accordance with the one exhibited in Table 3, suggesting that, when firms announce dividend increases, the market interprets a high PER as a signal that firms have less growth opportunities then expected, adjusting its perceptions downwards.

As we have already mentioned, Ross (1977) shows that good quality firms are able to differentiate themselves from lesser quality firms by assuming a higher leverage ratio. Consequently, we suppose that the events in the first group may be associated with higher levels of debt to equity ratio compared to the other events. It happens for all the samples, but the mean difference is only statistically significant for the Portuguese case. This result suggests, once more, that leverage and dividends are complementary signalling mechanisms.

Afterwards, we analyse the differences between the dividend decrease events with a negative market reaction and those with a positive reaction.

Looking for the mean differences, we can see that there are significant differences between the means of the firm size, the percentage change of dividends and the earnings growth for the UK, and between the means of earnings growth, of MB ratio and of PER for the French sample. For the Portuguese sample, none of the mean differences is statistically significant.

The firm size is smaller for the events with a negative market reaction to dividend decreases, as expected. This could be an indication that the market considers the information about smaller firms as worthy, because it is scarce, and reacts negatively to dividend decreases.

Regarding the percentage change of dividends, although we have a significant mean difference, the mean values for both types of events are similar.

In what concerns the earnings growth, the results of France and the UK are different. We expect that the past earnings growth could have some effect in the market reaction, according to their good or bad performance, contributing positively to the market 
reaction, in the former situation, and negatively in the later. Thus, we expect to find higher mean values for the events with a positive market reaction compared to the events with a negative reaction. Indeed, in the UK market, the mean earnings growth is negative for the events with a negative reaction to dividend decreases and is positive for the events with a positive market reaction. Once more, it suggests that earnings are at least as informative as dividends, or even more informative. This conclusion was found in prior research, such as in the works of Abeyratna and Power (2002) and Francis, Schipper and Vincent (2005), for single class shares in the US market. Surprisingly, in the French market, the behaviour is opposite, with positive earnings growth in the NRDD events and negative earnings growth in the PRDD events. Maybe the French investors do not consider the EG rate information to react in the event period. Indeed, we find no evidence for EG contributing to explain the market reaction in the dividend announcement period (Tables 2 and 3).

For the French market, the dividend decrease events with a negative market reaction present higher mean values for the MB ratio and for the PER. One possible reason for these results might be, for both the $\mathrm{MB}$ ratio and the PER, the fact that the market realises the high values of these ratios as a good new about future growth opportunities (associated with the information content perspective, and not with the free cash flow hypothesis), do not understanding the reason why, in these circumstances, firms decrease dividends, reacting worse in these situations (dividend decreases by firms with good prospects about future growth opportunities). Another reason could be the stage of the maturity of French firms with high ratios because of the low values of the denominators (book value of equity and earnings, respectively).

Summarising, the results exhibit evidence that, for the dividend increase events, the firm size, the market to book ratio and the price/earnings ratio tend to be higher for the events with a negative market reaction. The percentage change of dividends, the earnings growth and the debt/equity ratio tend to be lower for the events with a negative market reaction. These results could be interpreted as an indication that investors punish dividend increases when they have a lower magnitude, when the earnings growth is lower and when firms have strong growth prospects but increase dividends instead of retaining them to finance new projects.

For the dividend decrease events, the results are not so robust, but suggest that the firm size and the earnings growth (with the exception of the French sample) tend to be 
higher for the events with a positive market reaction and the price/earnings ratio tend to be lower in this type of events. This suggests that the market can react positively to dividend decreases when past earnings have grown.

\section{CONCLUSIONS}

Analysing the hypothesis that some firm-specific factors contribute to explain the cumulative abnormal return, we obtain the main results:

- When we consider all the dividend changes, the only markets where we have firm specific variables with power to explain the market abnormal returns in the announcement period are France and the UK. The explanatory variables that contribute in explaining the BHAR in the 3 days surrounding the dividend change announcements are the DE ratio, in the first market, and the earnings growth and the PER in the latter one. Although we find weak evidence of firmspecific variables influencing the market reaction surrounding the events period, the finding that investors have different expectations as to dividend announcements depending on a firm's prior history of earnings growth is consistent with the results of Healy, Hathorn and Kirch (1997);

- When we consider dividend increases and decreases separately the results are not very different. The only market where we have firm specific variables with power to explain the market abnormal returns in the announcement period is the UK. The explanatory variables that contribute in explaining the BHAR in the announcement period are the earnings growth, and, only for dividend increase events, the percentage change of dividends, the MB ratio and the PER. The evidence that the higher the dividend increases, the higher the market reaction suggests that the share price adjustment to dividend changes occurs in response to the information content of these decisions, which is consistent with the dividend signalling hypothesis and in agreement with several prior results, such as Eddy and Seifert (1992);

- The reason behind the evidence of some different signs for the distinct types of events (dividend increases and decreases) on the same firm-specific variable 
could be an indication that it is associated with the opposite relation between dividend change announcements and the subsequent market reaction;

- Globally, for the Portuguese and the French markets our evidence fails to support that there are firm-specific factors that contribute in a consistent way to explain the abnormal market return. The only country for which we find some evidence is the UK;

- Analysing the relation between the probability of a negative market reaction to dividend increase announcements and the firm-specific factors, the results suggest that firms with negative market reactions to dividend increase announcements have, on average, higher size, lower earnings growth rate and lower debt to equity ratios. Globally, these results are consistent with the ones of Ross (1977), Haw and Kim (1991), Eddy and Seifert (1992) and Mitra and Owners (1995). This evidence suggests that dividend increases of big firms with low earnings growth and low levels of debt can be seen as a bad new;

- Analysing the relation between the probability of a positive market reaction to dividend decrease announcements and the firm-specific factors, our results do not find support for a significant relationship between these variables, except for the French market, which evidence suggests that firms with positive market reactions to dividend decreases tend to have, on average, lower PER;

- The distinct results between the French and the UK samples could be related with differences in ownership and governance between the two countries. The first one is a bank based system with ownership concentration, where asymmetric information and agency problems are solved differently than in the latter country, which is a market-based system;

- When we compare the means differences of the firm-specific variables between the events with a positive and a negative market reaction for both the dividend increase and dividend decrease events, the findings indicate that, for the dividend increase events, the firm size, the market to book ratio and the price/earnings ratio tend to be higher for the events with a negative market reaction. The percentage change of dividends, the earnings growth and the debt/equity ratio tend to be lower for the events with a negative market reaction. The finding that firms with a positive reaction to dividend increases tend to have 
higher DE ratio suggests that firms signalling with dividends may be associated with higher levels of debt ratio, which is in accordance with Mougoué and Rao (2003). For the dividend decrease events, the results are not so robust, but suggest that the firm size and the earnings growth (with the exception of the French sample) tend to be higher for the events with a positive market reaction and the price/earnings ratio tend to be lower in this type of events;

- These results are an indication that investors penalise dividend increases when they have a lower magnitude, when the earnings growth are lower and when firms have a strong growth prospects but increase dividends instead of retain them to finance new project and suggests that the market can react positively to dividend decreases if the past earnings have grown;

- The finding indicating that, for the UK sample, earnings change announcements convey information beyond what is revealed by dividend change announcements is consistent with our previous results as well as with DeAngelo, DeAngelo and Skinner (1992), Abeyratna and Power (2002) and Francis, Schipper and Vincent (2005) evidence.

Globally speaking, and having in consideration the evidence obtained so far, the results suggest that in the UK, where information asymmetry is higher than in the other two countries considered in this study, managers tend to use dividends as a mechanism to mitigate it, which is in accordance with Lasfer and Zenonos (2004) evidence. In France and in Portugal, countries characterised by a bank-based system, and where information asymmetry is lower than in the UK, there is no pronounced need to use dividends to convey information to the market, being the signalling effect of dividends less important, which results validate the ones of Aivazian, Booth and Cleary (2003a) and Goergen, Renneboog and Silva (2005). Furthermore, this evidence is consistent with the axiom that there is a smaller signalling function in the bank-based system.

\section{SUGGESTIONS FOR FUTURE RESEARCH}

The phenomenon of an inverse relationship between dividend changes and market reaction in several studies motivate us for further research, such as the relation between firm specific factors and the market reaction in the dividend announcement period. 
For robustness reasons, we would like to explore different situations. Firstly, we will try to consider, in spite of the dividend changes, the dividend forecasts, when computing unexpected dividend changes, and the dividend yield ratio, in order to see if the main conclusions are unchanged. Secondly, we would like to consider, for the firm size variable, the assets value instead of the equity market value of common equity because of the different capital structures. Thirdly, we must consider market values in the computation of the debt to equity ratio. Finally, we think it is important to consider the yearly average of prices when calculating the PER, since the earnings are expressed in a yearly basis, and the price is referred to a specific moment.

Furthermore, we would like to analyse other variables, namely to explore the issue of the propriety firms' control, such as the free float and the firms' structure of property.

Finally, we believe that an interesting theme for future research and further development of this study would be the examination of country-specific variables, such as taxes, the financing system and the concentration of ownership equity with the purpose to analyse the different behaviour among the three country samples considered in this work. 


\section{REFERENCES}

Abeyratna, Gunasekarage and Power, David M., 2002, "The Post-announcement Performance of Dividend-changing Companies: The Dividend-signalling Hypothesis Revisited”, Accounting and Finance 42, 131-151.

Aharony, Joseph and Swary, Itzhak, 1980, "Quarterly Dividend and Earnings Announcements and Stockholders' Returns: An Empirical Analysis”, The Journal of Finance 35 (1), 1-12.

Aivazian, Varouj, Booth, Laurence and Cleary, Sean, 2003a, "Dividend Policy and the Organization of Capital Markets", Journal of Multinational Financial Management 13 (2), 101-121.

Aivazian, Varouj, Booth, Laurence and Cleary, Sean, 2003b, "Do Emerging Market Firms Follow Different Dividend Policies from U.S. Firms?”, The Journal of Financial Research 26 (3), 371-388.

Asquith, Paul and Mullins, David W., 1983, "The Impact of Initiating Dividend Payments on Shareholder Wealth”, The Journal of Business 56 (1), 77-96.

Benartzi, Shlomo, Michaely, Roni and Thaler, Richard, 1997, "Do Changes in Dividends Signal the Future or the Past?”, The Journal of Finance 52 (3), 1007-1034.

Benesh, Gary A., Keown, Arthur J. and Pinkerton, John M., 1984, “An Examination of Market Reaction to Substantial Shifts in Dividend Policy”, The Journal of Financial Research 7 (2), 131-142.

Born, Jeffery A., Moser, James T. and Officer, Dennis T., 1988, “Changes in Dividend Policy and Subsequent Earnings”, Journal of Portfolio Management 14 (4), 56-62.

Chen, Gongmeng, Firth, Michael and Gao, Ning, 2002, “The Information Content of Concurrently Announced Earnings, Cash Dividends, and Stock Dividends: An Investigation of the Chinese Stock Market", Journal of International Financial Management \& Accounting 13 (2), 101-124.

Conroy, Robert M., Eades, Kenneth M. and Harris, Robert S., 2000, “A Test of the Relative Pricing Effects of Dividends and Earnings: Evidence from Simultaneous Announcements in Japan”, The Journal of Finance 55 (3), 1199-1227.

DeAngelo, Harry, DeAngelo Linda and Skinner, Douglas J., 1992, "Dividends and Losses”, The Journal of Finance 47 (5), 1837-1863.

Dhillon, Upinder S. and Johnson, Herb, 1994, "The Effect of Dividend Changes on Stock and Bond Prices”, The Journal of Finance 49 (1), 281-289.

Eddy, Albert and Seifert, Bruce, 1988, "Firm Size and Dividend Announcements“, The Journal of Financial Research 11 (4), 295-302.

Francis, Jennifer, Schipper, Katherine and Vincent, Linda, 2005, "Earnings and Dividend Informativeness when Cash Flows are Separated from Voting Rights", Journal of Accounting and Economics 39 (2), 329-360.

Ghosh, Chinmoy and Woolridge, J. Randall, 1988, “An Analysis of Shareholder Reaction to Dividend Cuts and Omissions?”, The Journal of Financial Research 11 (4), 281-294. 
Goergen, Marc, Renneboog, Luc and Silva, Luis Correia, 2005, "When do German Firms Change their Dividends?”, Journal of Corporate Finance 11 (2), 375-399.

Gurgul, Henryk, Madjosz, Pawel and Mestel, Roland, 2003, "GARCH Modelling of Austrian Stock Market Reactions on Dividend Announcements”, Working Paper, VII Ogólnopolskie Seminarium Nauukowe.

Hausman, Jerry A., 1978, “Specification Tests in Econometrics”, Econometrica 46 (6), 1251-1271.

Haw, In-Mu H. and Kim, Wi-Saeng, 1991, "Firm Size and Dividend Announcement Effect”, Journal of Accounting, Auditing and Finance 6 (3), 325-347.

Healy, Joanne, Hathorn, John and Kirch, David, 1997, "Earnings and the Differential Information Content of Initial Dividend Announcements", Accounting Enquiries 6 (2), 187-220.

Hossain, Farhad, Siddiquee, Moniruzzaman and Rahman, Masud I., (2006), "Dividend Surprise and Market Reaction: Evidence from Dhaka Stock Exchange (DSE) Ltd.”, South Asian Journal of Management, Forthcoming.

Jensen, Michael, 1986, “Agency Costs of Free Cash Flow, Corporate Finance, and Takeover”, American Economic Review 76 (2), 323-329.

Kaplan, Steven N. and Zingales, Luigi, 1997, "Do Investment-cash Flow Sensitivities Provide Useful Measures of Financing Constraints?”, The Quarterly Journal of Economics 112 (1), 169-215.

Lamont, Owen A., Polk, Christopher and Saá-Requejo, Jesús, 2001, "Financial Constraints and Stock Returns”, The Review of Financial Studies 14 (2), 529-554.

Lang, Larry H.P. and Litzenberger, Robert H., 1989, "Dividend Announcements: Cash Flow Signalling Versus Free Cash Flow Hypothesis”, Journal of Financial Economics 24 (1), 181-191.

Lasfer, Meziane M. and Zenonos, Maria, 2004, "The Market Valuation of Dividend Announcements in the UK, Germany, France and Italy”, Working Paper presented at 2004 FMA Annual Meeting.

Lee, Hei Wai and Ryan, Patricia A., 2000, “The Information Content of Dividend Initiations and Omissions: The Free Cash Flow and Dividend Signaling Hypotheses”, The Journal of Research in Finance 3 (2), 196-277.

Lee, Hei Wai and Ryan, Patricia A., 2002, "Dividends and Earnings Revisited: Cause or Effect?”, American Business Review 20 (1), 117-122.

Lintner, John, 1956, "Distribution of Incomes of Corporations among Dividends, Retained Earnings and Taxes”, The American Economic Review 46 (2), 97-113.

Lippert, Robert L., Nixon, Terry D. and Pilotte, Eugene A., 2000, "Incentive Compensation and the Stock Price Response to Dividend Increase Announcements", The Financial Review 35, (4) 69-94.

Miller, Merton H. and Rock, Kevin, 1985, "Dividend Policy Under Asymmetric Information”, The Journal of Finance 40 (4), 1031-1051.

Mitra, Devashis and Owers, James E., 1995, "Dividend Initiation Announcement Effects and the Firm's Information Environment", Journal of Business Finance and Accounting 22 (4), 551-573. 
Mougoué, Mbodja and Rao, Ramesh P., 2003, “The Information Signaling Hypothesis of Dividends: Evidence from Cointegration and Causality Tests”, Journal of Business Finance \& Accounting 30 (3-4), 441-478.

Pettit, Richardson, 1972, "Dividend Announcements, Security Performance, and Capital Market Efficiency”, The Journal of Finance 27 (5), 993-1007.

Pettit, Richardson R., 1976, “The Impact of Dividends and Earnings Announcements: A Reconciliation”, The Journal of Business 49 (1), 86-96.

Ross, Stephen A., 1977, "The Determination of Financial Structure: The IncentiveSignalling Approach”, Bell Journal of Economics 8 (1), 23-40.

Travlos, Nickolaos, Trigeorgis, Lenos and Vafeas, Nikos, 2001, "Share-holder Wealth Effects of Dividend Policy Changes in an Emerging Stock Market: The Case of Cyprus”, Multinational Finance Journal 5 (2), 87-112.

Vieira, Elisabete F. S., 2005, "Signalling with Dividends? New Evidence from Europe”, Instituto Superior de Ciências do Trabalho e da Empresa (ISCTE), PhD Thesis.

White, Halbert, 1980, “A Heteroscedasticity-consistent Covariance Matrix Estimator and a Direct Test for Heteroscedasticity”, Econometrica 48 (4), 149-170.

Yilmaz, Mustafa K. and Gulay, Guzhan, 2006, "Dividend Policies and Price-Volume Reactions to Cash Dividends on the Stock Market: Evidence from the Istanbul Stock Exchange”, Emerging Markets, Finance \& Trade 42 (4), 19-49. 
TABLES 


\section{Table 1 - Sample Selection}

This table reports the number of dividend events (dividend increases and dividend decreases) for the Portuguese, the French and the UK samples, based on the study of Vieira (2005).

\begin{tabular}{lccc}
\hline \multicolumn{4}{c}{ Portuguese Sample } \\
\hline & $\begin{array}{c}\text { Dividend } \\
\text { Increases }\end{array}$ & $\begin{array}{c}\text { Dividend } \\
\text { Decreases }\end{array}$ & Total \\
\hline Dividend events & 158 & 121 & 279 \\
Events Percentage & $56,6 \%$ & $43,4 \%$ & $100,00 \%$ \\
\hline \multicolumn{4}{c}{ French Sample } \\
\hline Dividend events & 235 & 62 & 297 \\
Events Percentage & $79,1 \%$ & $20,9 \%$ & $100,00 \%$ \\
\hline & UK Sample & \\
\hline Dividend events & 2,623 & 266 & 2,889 \\
Events Percentage & $90,8 \%$ & $9,2 \%$ & $100,00 \%$ \\
\hline
\end{tabular}




\section{Table 2 - Regression of BHAR on firm specific variables and correlation matrix}

This table reports the estimation of a regression relating cumulative abnormal return (BHAR) in the announcement period to firm specific variables and the correlations between the independent variables. Panel A presents the Pearson correlations between independent variables. $\mathrm{FS}_{\mathrm{i}}$ is the firm size (natural log of market value of common equity at the end of the year before the dividend change year); $\mathrm{PCD}_{\mathrm{i}}$ is the percentage change of dividends (the annual change in dividends divided by the share price in the announcement day); $\mathrm{EG}_{\mathrm{i}}$ is the earnings growth rate (the average earnings growth rate based on the year prior to the dividend change year); $\mathrm{MB}_{\mathrm{i}}$ is the market to book ratio (market price per share at the dividend change announcement date divided by the book value per share at the end of the year before the dividend change year); $\mathrm{PER}_{\mathrm{i}}$ is the price earning ratio (the price per share at the announcement date divided by the earnings per share at the end of the year before the dividend change year); $\mathrm{DE}_{\mathrm{i}}$ is the debt to equity ratio (the book value of total debt divided by the total book value of equity at the end of the year prior to the dividend change announcement). Panel B presents the regression results estimated using pooled OLS, FEM and REM. The numbers in parentheses are the t-statistics corrected for heteroscedasticity using the White (1980) method. It reports the F test, a test for the equality of sets of coefficients, and the Hausman (1978) test, a test with $\mathrm{H}_{0}$ : random effects are consistent and efficient, versus $\mathrm{H}_{1}$ : random effects are inconsistent, in order to choose the most appropriate model for each particular sample.

\begin{tabular}{|c|c|c|c|c|c|c|}
\hline \multicolumn{7}{|c|}{ Panel A: Pearson correlations between independent variables (significance in parenthesis) } \\
\hline \multicolumn{7}{|c|}{ Portugal } \\
\hline \multirow{3}{*}{ Firm Size (FS) } & FS & PCD & EG & MB & PER & DE \\
\hline & 1.000 & -0.047 & 0.087 & $0.413^{*}$ & $0.211 *$ & 0.051 \\
\hline & & $(0.433)$ & $(0.145)$ & $(0.000)$ & $(0.000)$ & $(0.397)$ \\
\hline \multirow{2}{*}{ \% Change Div. (PCD) } & & 1.000 & $0.189 *$ & -0.031 & -0.025 & -0.019 \\
\hline & & & $(0.001)$ & $(0.603)$ & $(0.675)$ & $(0.748)$ \\
\hline \multirow[t]{2}{*}{ Earnings Growth (EG) } & & & 1.000 & 0.026 & -0.056 & 0.001 \\
\hline & & & & $(0.670)$ & $(0.350)$ & $(0.990)$ \\
\hline \multirow[t]{2}{*}{ Market to Book (MB) } & & & & 1.000 & $0.488^{*}$ & 0.141 \\
\hline & & & & & $(0.000)$ & $(0.018)$ \\
\hline \multirow[t]{2}{*}{ PER } & & & & & 1.000 & 0.007 \\
\hline & & & & & & $(0.907)$ \\
\hline \multirow[t]{3}{*}{ Debt/Equity (DE) } & & & & & & 1.000 \\
\hline & & & & & & \\
\hline & FS & PCD & EG & MB & PER & DE \\
\hline \multirow[t]{2}{*}{ Firm Size (FS) } & 1.000 & 0.078 & 0.021 & $0.370^{*}$ & 0.091 & $0.127^{* *}$ \\
\hline & & $(0.178)$ & $(0.717)$ & $(0.000)$ & $(0.116)$ & $(0.029)$ \\
\hline \multirow[t]{2}{*}{ \% Change Div. (PCD) } & & 1.000 & 0.001 & 0.020 & -0.015 & -0.079 \\
\hline & & & $(0.984)$ & $(0.731)$ & $(0.799)$ & $(0.173)$ \\
\hline \multirow[t]{2}{*}{ Earnings Growth (EG) } & & & 1.000 & 0.086 & $0.154^{*}$ & 0.033 \\
\hline & & & & $(0.137)$ & $(0.008)$ & $(0.575)$ \\
\hline \multirow[t]{2}{*}{ Market to Book (MB) } & & & & 1.000 & $0.371 *$ & $-0.216^{*}$ \\
\hline & & & & & $(0.000)$ & $(0.000)$ \\
\hline \multirow[t]{2}{*}{ PER } & & & & & 1.000 & -0.060 \\
\hline & & & & & & $(0.305)$ \\
\hline Debt/Equity (DE) & & & & & & 1.000 \\
\hline
\end{tabular}

* $\quad$ Significantly different from zero at the $1 \%$ level

** $\quad$ Significantly different from zero at the $5 \%$ level

*** Significantly different from zero at the $10 \%$ level 
Table 2 - Regression of BHAR on firm specific variables and correlation matrix

(continued)

\begin{tabular}{|c|c|c|c|c|c|c|}
\hline \multicolumn{7}{|c|}{ UK } \\
\hline \multirow{3}{*}{ Firm Size (FS) } & FS & PCD & EG & MB & PER & DE \\
\hline & 1.000 & 0.024 & -0.008 & $0.127 *$ & $0.184^{*}$ & $0.115^{*}$ \\
\hline & & $(0.201)$ & $(0.677)$ & $(0.000)$ & $(0.000)$ & $(0.000)$ \\
\hline \multirow[t]{2}{*}{ \% Change Div. (PCD) } & & 1.000 & 0.026 & 0.034 & -0.018 & -0.012 \\
\hline & & & $(0.163)$ & $(0.072)$ & $(0.340)$ & $(0.536)$ \\
\hline \multirow[t]{2}{*}{ Earnings Growth (EG) } & & & 1.000 & 0.001 & 0.017 & $-0.045^{* *}$ \\
\hline & & & & $(0.965)$ & $(0.365)$ & $(0.015)$ \\
\hline \multirow[t]{2}{*}{ Market to Book (MB) } & & & & 1.000 & $0.313^{*}$ & $0.402 *$ \\
\hline & & & & & $(0.000)$ & $(0.000)$ \\
\hline \multirow[t]{2}{*}{ PER } & & & & & 1.000 & 0.023 \\
\hline & & & & & & $(0.219)$ \\
\hline Debt/Equity (DE) & & & & & & 1.000 \\
\hline
\end{tabular}

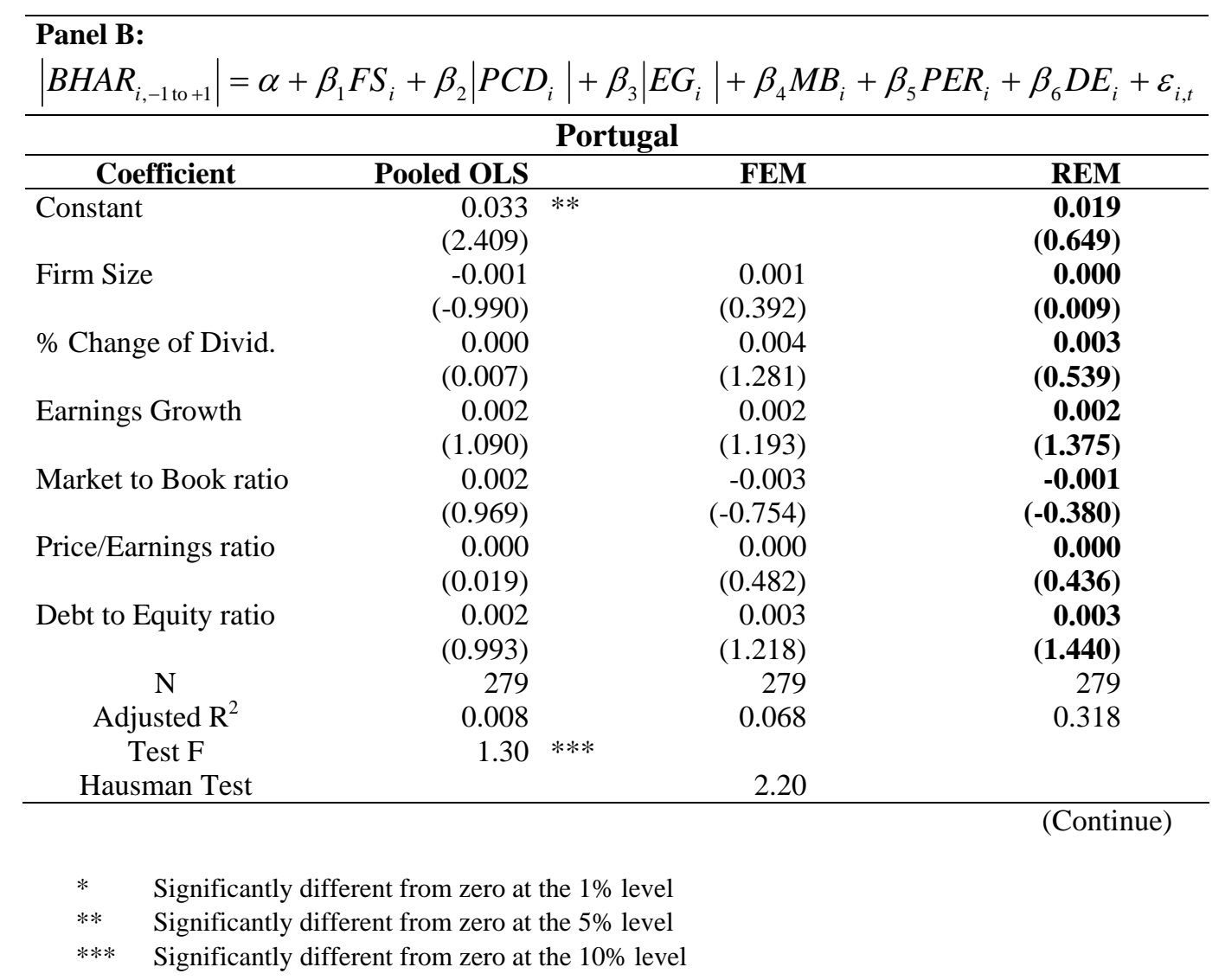


Table 2 - Regression of BHAR on firm specific variables and correlation matrix (continued)

\begin{tabular}{|c|c|c|c|c|c|c|}
\hline Panel B: & $F S_{i}+\beta_{2} \mid P C D$ & $i \mid+\rho$ & $G_{i} \mid+\beta_{4} M$ & $B_{i}+$ & $R_{i}+\beta_{6} D E_{i}+$ & $\varepsilon_{i, t}$ \\
\hline \multicolumn{7}{|c|}{ France } \\
\hline Coefficient & Pooled OLS & & FEM & & REM & \\
\hline Constant & $\begin{array}{r}0.041 \\
(3.229)\end{array}$ & * & & & $\begin{array}{r}0.019 \\
(0.872)\end{array}$ & \\
\hline Firm Size & $\begin{array}{r}-0.001 \\
(-0.903)\end{array}$ & & $\begin{array}{r}0.005 \\
(1.590)\end{array}$ & & $\begin{array}{r}0.001 \\
(0.333)\end{array}$ & \\
\hline \% Change of Divid. & $\begin{array}{r}-0.024 \\
(-0.247)\end{array}$ & & $\begin{array}{r}0.216 \\
(1.308)\end{array}$ & & $\begin{array}{r}0.070 \\
(0.521)\end{array}$ & \\
\hline Earnings Growth & $\begin{array}{r}-0.001 \\
(-1.743)\end{array}$ & $* * *$ & $\begin{array}{r}-0.001 \\
(-0.313)\end{array}$ & & $\begin{array}{r}-0.001 \\
(-0.551)\end{array}$ & \\
\hline Market to Book ratio & $\begin{array}{r}-0.000 \\
(-0.059)\end{array}$ & & $\begin{array}{r}-0.008 \\
(-2.086)\end{array}$ & $* *$ & $\begin{array}{r}-0.002 \\
(-0.772)\end{array}$ & \\
\hline Price/Earnings ratio & $\begin{array}{r}-0.001 \\
(-0.916)\end{array}$ & & $\begin{array}{r}0.000 \\
(0.374)\end{array}$ & & $\begin{array}{r}-0.000 \\
(-0.043)\end{array}$ & \\
\hline Debt to Equity ratio & $\begin{array}{r}0.004 \\
(1.658)\end{array}$ & $* * *$ & $\begin{array}{r}0.005 \\
(1.106)\end{array}$ & & $\begin{array}{r}0.005 \\
(1.777)\end{array}$ & $* * *$ \\
\hline $\mathrm{N}$ & 297 & & 297 & & 297 & \\
\hline Adjusted $\mathrm{R}^{2}$ & 0.001 & & 0.068 & & 0.350 & \\
\hline Test $\mathrm{F}$ & 1.35 & $* *$ & 0.096 & & & \\
\hline Hausman Test & & & 6.51 & & & \\
\hline & & $\overline{\mathbf{U}}$ & & & & \\
\hline Coefficient & Pooled OLS & & FEM & & REM & \\
\hline Constant & $\begin{array}{r}0.079 \\
(7.895)\end{array}$ & $*$ & & & $\begin{array}{r}0.071 \\
(5.617)\end{array}$ & \\
\hline Firm Size & $\begin{array}{r}-0.002 \\
(-3.021)\end{array}$ & * & $\begin{array}{r}0.003 \\
(1.691)\end{array}$ & $* * *$ & $\begin{array}{r}-0.001 \\
(-1.566)\end{array}$ & \\
\hline \% Change of Divid. & $\begin{array}{r}0.196 \\
(2.375)\end{array}$ & $* *$ & $\begin{array}{r}0.072 \\
(0.826)\end{array}$ & & $\begin{array}{r}0.114 \\
(1.234)\end{array}$ & \\
\hline Earnings Growth & $\begin{array}{r}0.007 \\
(4.613)\end{array}$ & * & $\begin{array}{r}0.006 \\
(3.829)\end{array}$ & * & $\begin{array}{r}0.006 \\
(4.557)\end{array}$ & $*$ \\
\hline Market to Book ratio & $\begin{array}{r}0.001 \\
(2.554)\end{array}$ & $* *$ & $\begin{array}{r}-0.001 \\
(-0.654)\end{array}$ & & $\begin{array}{r}0.001 \\
(1.140)\end{array}$ & \\
\hline Price/Earnings ratio & $\begin{array}{r}-0.000 \\
(-1.387)\end{array}$ & & $\begin{array}{r}-0.001 \\
(-3.212)\end{array}$ & * & $\begin{array}{r}-0.001 \\
(-1.981)\end{array}$ & $* *$ \\
\hline Debt to Equity ratio & $\begin{array}{r}0.000 \\
(0.022)\end{array}$ & & $\begin{array}{r}0.007 \\
(2.559)\end{array}$ & $* *$ & $\begin{array}{r}0.002 \\
(1.089)\end{array}$ & \\
\hline $\mathrm{N}$ & 2,889 & & 2,889 & & 2,889 & \\
\hline Adjusted $\mathrm{R}^{2}$ & 0.018 & & 0.079 & & 0.207 & \\
\hline Test $\mathrm{F}$ & 1.38 & * & & & & \\
\hline Hausman Test & & & 3.47 & & & \\
\hline
\end{tabular}

* $\quad$ Significantly different from zero at the $1 \%$ level

** $\quad$ Significantly different from zero at the 5\% level

$* * * \quad$ Significantly different from zero at the $10 \%$ level 


\section{Table 3 - Regression of BHAR on firm specific variables with dummies}

This table reports the estimation of a regression relating the BHAR in the event period to firm specific factors using dummy variables to identify dividend increase and decrease events. $\mathrm{FS}_{\mathrm{i}}$ is the firm size, computed as the natural log of market value of common equity at the end of the year before the dividend change year; $\mathrm{PCD}_{\mathrm{i}}$ is the percentage change of dividends, computed as the annual change in dividends divided by the share price in the announcement day; $\mathrm{EG}_{\mathrm{i}}$ is the earnings growth rate, computed as the average earnings growth rate based on the year prior to the dividend change year; $M B_{i}$ is the market to book ratio, calculated by dividing the market price per share at the dividend change announcement date by the book value per share at the end of the year before the dividend change year; $\mathrm{DE}_{\mathrm{i}}$ is the debt to equity ratio, calculated as the book value of total debt divided by the total book value of equity at the end of the year prior to the dividend change announcement; DI (DD) is a dummy variable that takes the value 1 if dividend increases (decreases) and 0 otherwise; $\Phi$ is the vector of coefficients for the dummy variables relating dividend and earnings changes, set equal to 1 respectively, if both dividend and earnings increases, dividend increases and earnings decreases, dividend decreases and earnings increases, both dividend and earnings decreases, and 0 otherwise. The regression results are estimated using pooled OLS, FEM and REM. The numbers in parentheses are the t-statistics corrected for heteroscedasticity using the White (1980) method. It reports the F test, a test for the equality of sets of coefficients, and the Hausman (1978) test, a test with $\mathrm{H}_{0}$ : random effects are consistent and efficient, versus $\mathrm{H}_{1}$ : random effects are inconsistent, in order to choose the most appropriate model for each particular sample.

\begin{tabular}{|c|c|c|c|}
\hline \multirow{2}{*}{\multicolumn{4}{|c|}{ 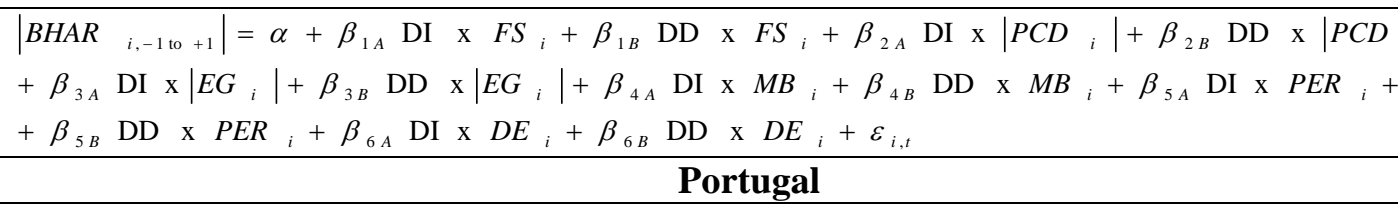 }} \\
\hline & & & \\
\hline $\begin{array}{l}\text { Coefficient } \\
\end{array}$ & Pooled OLS & FEM & REM \\
\hline Constant & $\begin{array}{r}0.034 \\
(2.229)\end{array}$ & $* *$ & $\begin{array}{r}0.018 \\
(0.603)\end{array}$ \\
\hline DI $x$ FS & $\begin{array}{r}-0.001 \\
(-0.846)\end{array}$ & $\begin{array}{r}0.001 \\
(0.457)\end{array}$ & $\begin{array}{r}0.000 \\
(0.031)\end{array}$ \\
\hline $\mathrm{DD} \times \mathrm{FS}$ & $\begin{array}{r}-0.001 \\
(-1.064)\end{array}$ & $\begin{array}{r}0.001 \\
(0.530)\end{array}$ & $\begin{array}{r}0.000 \\
(0.082)\end{array}$ \\
\hline DI x PCD & $\begin{array}{r}-0.000 \\
(-0.010)\end{array}$ & $\begin{array}{r}0.004 \\
(1.278)\end{array}$ & $\begin{array}{r}0.004 \\
(0.533)\end{array}$ \\
\hline $\mathrm{DD} \times \mathrm{PCD}$ & $\begin{array}{r}-0.003 \\
(-0.160)\end{array}$ & $\begin{array}{r}0.005 \\
(0.234)\end{array}$ & $\begin{array}{r}0.004 \\
(0.123)\end{array}$ \\
\hline DI x EG & $\begin{array}{r}0.002 \\
(0.993)\end{array}$ & $\begin{array}{r}0.002 \\
(1.093)\end{array}$ & $\begin{array}{r}0.002 \\
(1.322)\end{array}$ \\
\hline DD x EG & $\begin{array}{r}0.001 \\
(0.213)\end{array}$ & $\begin{array}{r}0.001 \\
(0.312)\end{array}$ & $\begin{array}{r}0.001 \\
(0.211)\end{array}$ \\
\hline DI x MB & $\begin{array}{r}0.004 \\
(0.841)\end{array}$ & $\begin{array}{r}-0.000 \\
(-0.027)\end{array}$ & $\begin{array}{r}0.001 \\
(0.262)\end{array}$ \\
\hline $\mathrm{DD} \times \mathrm{MB}$ & $\begin{array}{r}0.000 \\
(0.378)\end{array}$ & $\begin{array}{r}-0.006 \\
(-1.373)\end{array}$ & $\begin{array}{r}-0.004 \\
(-0.826)\end{array}$ \\
\hline DI x PER & $\begin{array}{r}-0.000 \\
(-0.839)\end{array}$ & $\begin{array}{r}-0.000 \\
(-0.607)\end{array}$ & $\begin{array}{r}-0.000 \\
(-0.476)\end{array}$ \\
\hline DD $x$ PER & $\begin{array}{r}0.002 \\
(1.359)\end{array}$ & $\begin{array}{r}0.000 \\
(1.306)\end{array}$ & $\begin{array}{r}0.000 \\
(0.947)\end{array}$ \\
\hline DI x DE & $\begin{array}{r}0.002 \\
(0.803)\end{array}$ & $\begin{array}{r}0.003 \\
(1.091)\end{array}$ & $\begin{array}{r}0.003 \\
(1.304)\end{array}$ \\
\hline DD x DE & $\begin{array}{r}0.002 \\
(0.586)\end{array}$ & $\begin{array}{r}0.002 \\
(0.408)\end{array}$ & $\begin{array}{r}0.002 \\
(0.436)\end{array}$ \\
\hline $\begin{array}{c}\mathrm{N} \\
\text { Adjusted } \mathrm{R}^{2}\end{array}$ & $\begin{array}{r}279 \\
0.026\end{array}$ & $\begin{array}{r}279 \\
0.047\end{array}$ & $\begin{array}{r}279 \\
0.309\end{array}$ \\
\hline $\begin{array}{c}\text { Test F } \\
\text { Hausman Test }\end{array}$ & 1.28 & $* * *$ & \\
\hline
\end{tabular}


Table 3 - Regression of BHAR on firm specific variables with dummies (continued)

\begin{tabular}{|c|c|c|c|c|c|}
\hline \multicolumn{6}{|c|}{ 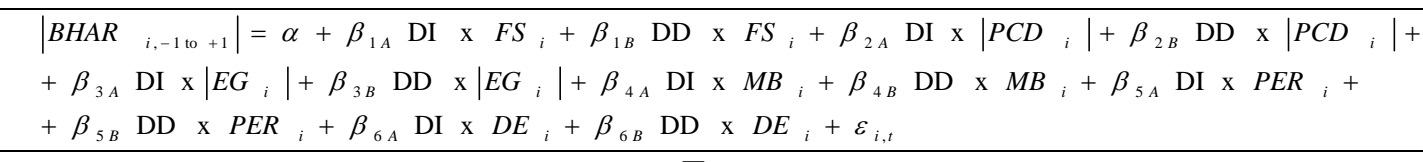 } \\
\hline \multicolumn{6}{|c|}{ France } \\
\hline Coefficient & Pooled OLS & & FEM & & REM \\
\hline Constant & $\begin{array}{r}0.038 \\
(2.959)\end{array}$ & * & & & $\begin{array}{r}0.016 \\
(0.710)\end{array}$ \\
\hline DI $x$ FS & $\begin{array}{r}-0.001 \\
(-0.593)\end{array}$ & & $\begin{array}{r}0.006 \\
(1.915)\end{array}$ & $* * *$ & $\begin{array}{r}0.001 \\
(0.503)\end{array}$ \\
\hline DD x FS & $\begin{array}{r}-0.001 \\
(-0.526)\end{array}$ & & $\begin{array}{r}0.007 \\
(1.945)\end{array}$ & $* * *$ & $\begin{array}{r}0.001 \\
(0.649)\end{array}$ \\
\hline DI x PCD & $\begin{array}{r}0.138 \\
(0.771)\end{array}$ & & $\begin{array}{r}0.448 \\
(1.999)\end{array}$ & $* *$ & $\begin{array}{r}0.207 \\
(0.988)\end{array}$ \\
\hline $\mathrm{DD} \times \mathrm{PCD}$ & $\begin{array}{r}-0.102 \\
(-1.251)\end{array}$ & & $\begin{array}{r}0.212 \\
(1.347)\end{array}$ & & $\begin{array}{r}0.027 \\
(0.192)\end{array}$ \\
\hline DI x EG & $\begin{array}{r}-0.001 \\
(-0.742)\end{array}$ & & $\begin{array}{r}0.008 \\
(0.589)\end{array}$ & & $\begin{array}{r}0.000 \\
(0.043)\end{array}$ \\
\hline DD x EG & $\begin{array}{r}-0.002 \\
(-1.202)\end{array}$ & & $\begin{array}{r}-0.004 \\
(-1.529)\end{array}$ & & $\begin{array}{r}-0.003 \\
(-0.990)\end{array}$ \\
\hline DI x MB & $\begin{array}{r}-0.001 \\
(-0.449)\end{array}$ & & $\begin{array}{r}-0.009 \\
(-2.272)\end{array}$ & $* *$ & $\begin{array}{r}-0.002 \\
(-0.764)\end{array}$ \\
\hline $\mathrm{DD} \times \mathrm{MB}$ & $\begin{array}{r}-0.001 \\
(-0.427)\end{array}$ & & $\begin{array}{r}-0.011 \\
(-2.557)\end{array}$ & $* *$ & $\begin{array}{r}-0.004 \\
(-1.015)\end{array}$ \\
\hline DI x PER & $\begin{array}{r}0.000 \\
(0.020)\end{array}$ & & $\begin{array}{r}0.000 \\
(0.393)\end{array}$ & & $\begin{array}{r}0.000 \\
(0.182)\end{array}$ \\
\hline DD $x$ PER & $\begin{array}{r}-0.000 \\
(-1.307)\end{array}$ & & $\begin{array}{r}-0.000 \\
(-0.537)\end{array}$ & & $\begin{array}{r}-0.000 \\
(-0.582)\end{array}$ \\
\hline DI x DE & $\begin{array}{r}0.000 \\
(0.170)\end{array}$ & & $\begin{array}{r}0.003 \\
(0.517)\end{array}$ & & $\begin{array}{r}0.002 \\
(0.653)\end{array}$ \\
\hline $\mathrm{DD} \times \mathrm{DE}$ & $\begin{array}{r}0.006 \\
(1.979)\end{array}$ & $* *$ & $\begin{array}{r}0.004 \\
(0.808)\end{array}$ & & $\begin{array}{r}0.005 \\
(1.561)\end{array}$ \\
\hline $\mathrm{N}$ & 297 & & 297 & & 297 \\
\hline Adjusted $\mathrm{R}^{2}$ & 0.007 & & 0.081 & & 0.342 \\
\hline $\begin{array}{c}\text { Test F } \\
\text { Hausman Test }\end{array}$ & 1.30 & *** & 12.25 & & \\
\hline
\end{tabular}

(Continue)

* $\quad$ Significantly different from zero at the $1 \%$ level

** $\quad$ Significantly different from zero at the $5 \%$ level

*** Significantly different from zero at the $10 \%$ level 
Table 3 - Regression of BHAR on firm specific variables with dummies (continued)

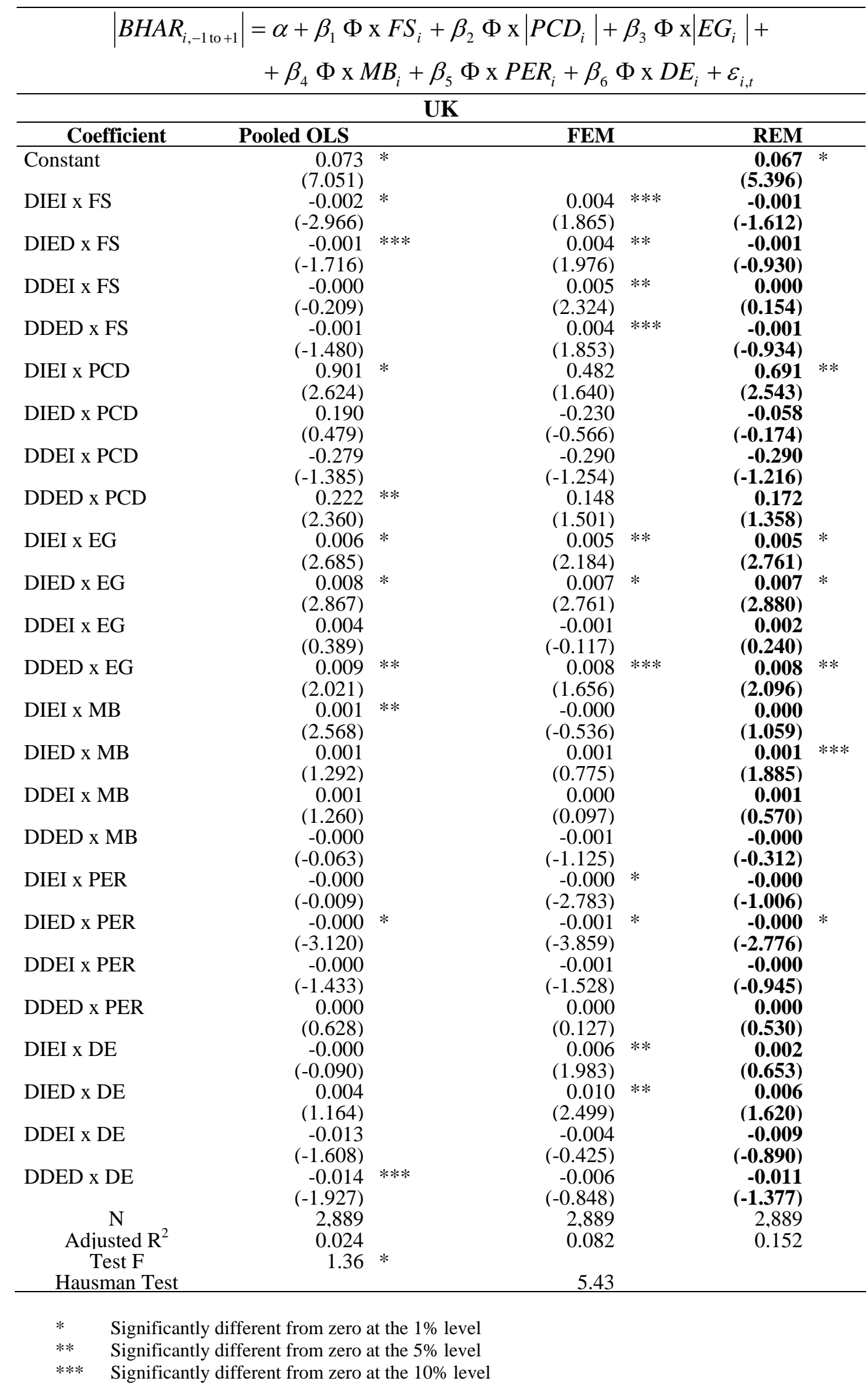




\section{Table 4 - Logistic regression of the negative (positive) reaction to dividend increase (decrease) announcements and firm specific variables}

This table reports the estimation of a logistic regression relating the negative reaction to dividend increase announcements (Panel A) and the positive reaction to dividend decrease announcements (Panel B) and firm specific variables. $B H A R I_{i,-1}$ to +1 is a dummy variable that takes value 1 if $\mathrm{BHAR}_{\mathrm{i},-1 \mathrm{to}^{+1}}$ is negative and 0 otherwise; $\mathrm{BHARD}_{\mathrm{i},-1}$ to +1 is a dummy variable that takes value 1 if $\mathrm{BHAR}_{\mathrm{i},-1 \mathrm{to}+1}$ is positive and 0 otherwise; $\mathrm{FS}_{\mathrm{i}}$ is the firm size, computed as the natural $\log$ of market value of common equity at the end of the year before the dividend change year; $\mathrm{LPCD}_{\mathrm{i}}$ is the natural logarithm of annual change in dividends divided by the share price in the announcement day $+1 ; L_{E G}$ is the natural logarithm of average earnings growth rate based on the year prior to the dividend change year +1 ; $\mathrm{MB}_{\mathrm{i}}$ is natural logarithm of market price per share at the dividend change announcement date by the book value per share at the end of the year before the dividend change year +1 ; $\mathrm{LE}_{\mathrm{i}}$ is the natural logarithm of book value of total debt divided by the total book value of equity at the end of the year prior to the dividend change announcement +1 . We report the coefficient values and the $p$-values.

\begin{tabular}{|c|c|c|c|c|}
\hline \multicolumn{5}{|c|}{ Panel A: Dividend Increases } \\
\hline \multicolumn{5}{|c|}{ BHARI $_{i,-1 \mathrm{to}+1}=\alpha+\beta_{1} F S_{i}+\beta_{2} \mathrm{LPCD}_{1}+\beta_{3} \mathrm{LEG}_{\mathrm{i}}+\beta_{4} L M B_{1}+\beta_{5} L P E R_{t}+\beta_{6} L D E_{i}+\varepsilon_{t}$} \\
\hline \multicolumn{5}{|c|}{$\begin{array}{ll} & \text { Portugal } \\
\end{array}$} \\
\hline & Coefficient & p-value & \\
\hline \multicolumn{2}{|c|}{ Constant } & 3.506 & 0.067 & $* * *$ \\
\hline \multicolumn{2}{|c|}{ Firm Size } & -0.123 & 0.263 & \\
\hline \multicolumn{2}{|c|}{ Log \% Change of Dividends } & -5.301 & 0.230 & \\
\hline \multicolumn{2}{|c|}{ Log Earnings Growth } & -1.311 & 0.005 & * \\
\hline \multicolumn{2}{|c|}{ Log Market to Book ratio } & -0.671 & 0.319 & \\
\hline \multicolumn{2}{|c|}{ Log Price/Earnings ratio } & -0.031 & 0.913 & \\
\hline \multicolumn{2}{|c|}{ Log Debt to Equity ratio } & -0.930 & 0.059 & $* * *$ \\
\hline \multicolumn{2}{|c|}{$\mathrm{N}$} & 158 & & \\
\hline \multicolumn{2}{|c|}{ Nagelkerke $\mathrm{R}^{2}$} & 0.169 & & \\
\hline \multicolumn{5}{|c|}{ France } \\
\hline \multirow{2}{*}{\multicolumn{2}{|c|}{ Constant }} & Coefficient & p-value & \\
\hline & & -0.759 & 0.597 & \\
\hline \multicolumn{2}{|c|}{ Firm Size } & 0.049 & 0.596 & \\
\hline \multicolumn{2}{|c|}{ Log \% Change of Dividends } & 4.809 & 0.721 & \\
\hline \multicolumn{2}{|c|}{ Log Earnings Growth } & -0.610 & 0.101 & \\
\hline \multicolumn{2}{|c|}{ Log Market to Book ratio } & -0.816 & 0.076 & $* * *$ \\
\hline \multicolumn{2}{|c|}{ Log Price/Earnings ratio } & 0.220 & 0.422 & \\
\hline \multicolumn{2}{|c|}{ Log Debt to Equity ratio } & -0.249 & 0.523 & \\
\hline \multicolumn{2}{|l|}{$\mathrm{N}$} & 235 & & \\
\hline \multirow{2}{*}{\multicolumn{2}{|c|}{ Nagelkerke $\mathrm{R}^{2}$}} & 0.035 & & \\
\hline & & & \multicolumn{2}{|c|}{ (Continue) } \\
\hline $\begin{array}{l}* \\
* * \\
* * *\end{array}$ & \multicolumn{4}{|c|}{$\begin{array}{l}\text { Significantly different from zero at the } 1 \% \text { level } \\
\text { Significantly different from zero at the } 5 \% \text { level } \\
\text { Significantly different from zero at the } 10 \% \text { level }\end{array}$} \\
\hline
\end{tabular}


Table 4 - Logistic regression of the negative (positive) reaction to dividend increase (decrease) announcements and firm specific variables (continued)

\begin{tabular}{|c|c|c|c|}
\hline \multicolumn{4}{|l|}{$\begin{array}{l}\text { Panel A: Dividend Increases } \\
B H A R I_{,-1 \text { to }+1}=\alpha+\beta_{1} F S_{i}+\beta_{2} L P\end{array}$} \\
\hline \multicolumn{4}{|c|}{ UK } \\
\hline & Coefficient & p-value & \\
\hline Constant & -1.601 & 0.000 & $*$ \\
\hline Firm Size & 0.059 & 0.011 & $* *$ \\
\hline Log \% Change of Dividends & 0.594 & 0.944 & \\
\hline Log Earnings Growth & 0.053 & 0.666 & \\
\hline Log Market to Book ratio & 0.165 & 0.031 & $* *$ \\
\hline Log Price/Earnings ratio & 0.010 & 0.918 & \\
\hline Log Debt to Equity ratio & -0.326 & 0.015 & $* *$ \\
\hline $\mathrm{N}$ & 2,623 & & \\
\hline Nagelkerke $\mathrm{R}^{2}$ & 0.092 & & \\
\hline
\end{tabular}

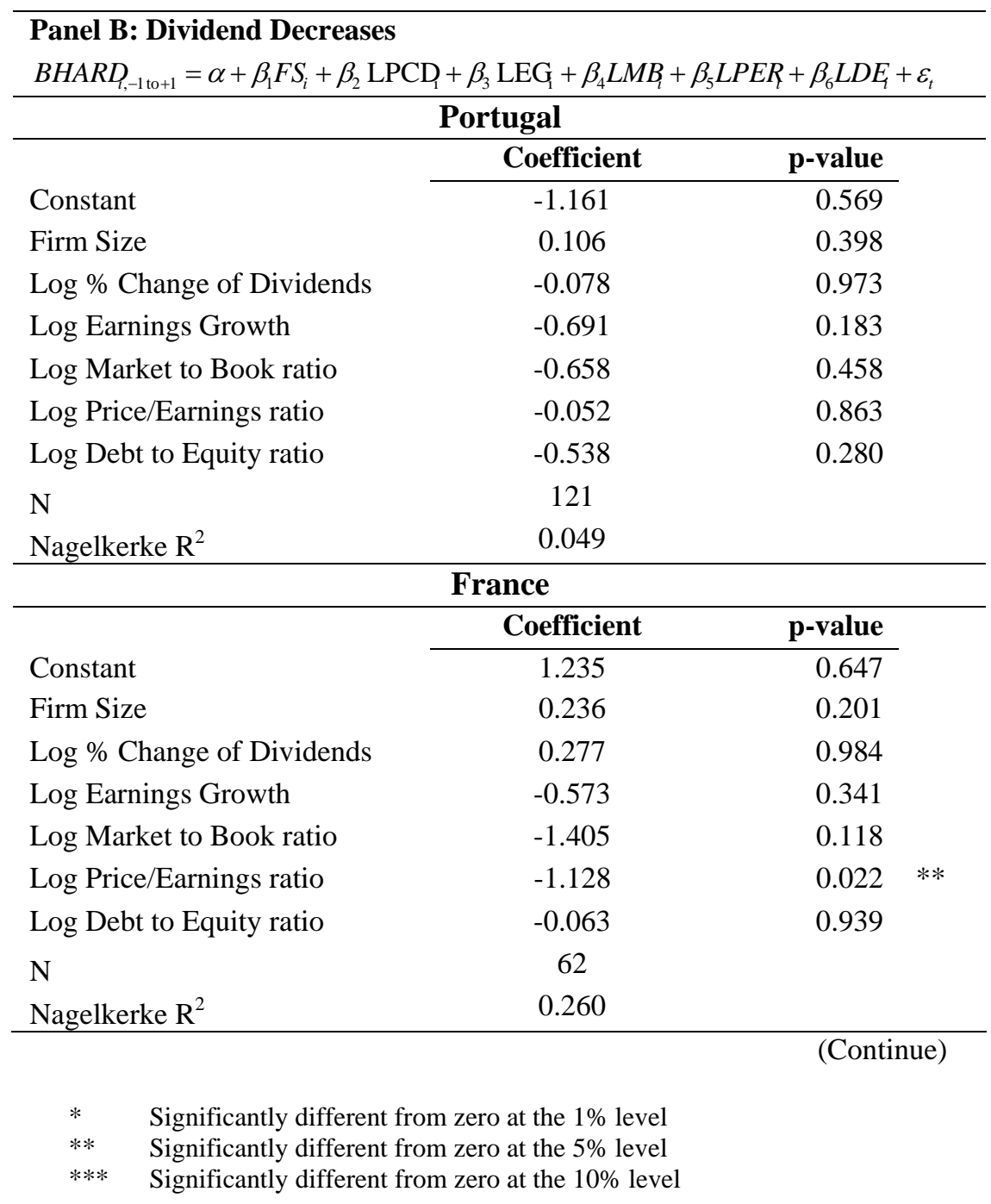


Table 4 - Logistic regression of the negative (positive) reaction to dividend increase (decrease) announcements and firm specific variables (continued)

\begin{tabular}{|c|c|c|}
\hline \multicolumn{3}{|l|}{ Panel B: Dividend Decreases } \\
\hline & UK & \\
\hline & Coefficient & p-value \\
\hline Constant & -0.963 & 0.401 \\
\hline Firm Size & 0.060 & 0.349 \\
\hline Log \% Change of Dividends & 3.309 & 0.508 \\
\hline Log Earnings Growth & 0.246 & 0.418 \\
\hline Log Market to Book ratio & 0.155 & 0.543 \\
\hline Log Price/Earnings ratio & -0.012 & 0.960 \\
\hline Log Debt to Equity ratio & -0.164 & 0.706 \\
\hline $\mathrm{N}$ & 266 & \\
\hline Nagelkerke $\mathrm{R}^{2}$ & 0.130 & \\
\hline
\end{tabular}

* $\quad$ Significantly different from zero at the $1 \%$ level

** $\quad$ Significantly different from zero at the 5\% level

*** $\quad$ Significantly different from zero at the $10 \%$ level 


\section{Table 5 - Selected specific variables for the sub-samples of events, according to the relationship between dividend change announcements and the BHAR}

This table reports the mean values of selected specific factors for the different groups classified according to the relation between dividend change announcements and the subsequent market reaction. $\mathrm{FS}_{\mathrm{i}}$ is the firm size for share i, computed as the natural log of market value of common equity at the end of the year before the dividend change year; $\mathrm{PCD}_{\mathrm{i}}$ is the percentage change of dividends for share $\mathrm{i}$, computed as the annual change in dividends divided by the share price in the announcement day; $\mathrm{EG}_{\mathrm{i}}$ is the earnings growth rate for share $\mathrm{i}$, computed as the average earnings growth rate based on the year prior to the dividend change year; $\mathrm{MB}_{\mathrm{i}}$ is the market to book ratio for share $\mathrm{i}$, calculated by dividing the market price per share at the dividend change announcement date by the book value per share at the end of the year before the dividend change year; $\mathrm{PER}_{\mathrm{i}}$ is the price earning ratio for share $\mathrm{i}$, computed as the price per share at the announcement date divided by the earnings per share at the end of the year before the dividend change year; $\mathrm{DE}_{\mathrm{i}}$ is the debt/equity ratio for share $\mathrm{i}$, calculated as the book value of total debt divided by the total book value of equity at the end of the year prior to the dividend change announcement; PRDI identifies the events with a positive reaction to dividend increases; NRDD identifies the events with a negative reaction to dividend decreases; NRDI identifies the events with a negative reaction to dividend increases; PRDD identifies the events with a positive reaction to dividend decreases. In addition, the table also presents the value of the $t$-statistic to test for the differences between the means of two groups.

\begin{tabular}{|c|c|c|c|c|c|c|c|c|}
\hline \multicolumn{9}{|c|}{ Relation between dividend changes and BHAR } \\
\hline Variables & $\begin{array}{l}\text { PRDI } \\
\text { (I) }\end{array}$ & $\begin{array}{c}\text { NRDI } \\
\text { (II) }\end{array}$ & $\begin{array}{l}\text { t - statis } \\
\text { (I)-(II) }\end{array}$ & & $\begin{array}{c}\text { NRDD } \\
\text { (III) }\end{array}$ & $\begin{array}{c}\text { PRDD } \\
\text { (IV) }\end{array}$ & \multicolumn{2}{|c|}{$\begin{array}{l}\text { t - statistic } \\
\text { (III)-(IV) }\end{array}$} \\
\hline \multicolumn{9}{|c|}{ Portugal } \\
\hline Firm size & 17.118 & 16.762 & 1.574 & & 17.019 & 17.122 & -0.443 & \\
\hline \% Change in dividends & 0.082 & 0.026 & 1.023 & & -0.078 & -0.075 & 0.726 & \\
\hline Earnings growth & 0.892 & 0.292 & 3.253 & * & 0.116 & -0.049 & -0.72 & \\
\hline Market to book ratio & 0.868 & 0.810 & 0.536 & & 0.828 & 0.718 & 0.891 & \\
\hline Price/earnings ratio & 9.548 & 10.296 & -0.195 & & 11.223 & 12.313 & -0.132 & \\
\hline Debt/Equity ratio & 1.015 & 0.659 & 2.668 & * & 1.044 & 0.781 & 1.013 & \\
\hline \multicolumn{9}{|c|}{ France } \\
\hline Firm size & 13.711 & 13.583 & 0.853 & & 13.426 & 13.630 & -0.392 & \\
\hline \% Change in dividends & 0.004 & 0.004 & 0.301 & & -0.009 & -0.014 & 0.731 & \\
\hline Earnings growth & 0.365 & 0.325 & 0.438 & & 0.810 & -0.040 & 1.708 & $* * *$ \\
\hline Market to book ratio & 0.856 & 0.672 & 1.760 & $* * *$ & 1.209 & 0.638 & 2.116 & $* *$ \\
\hline Price/earnings ratio & 22.972 & 22.696 & 0.462 & & 25.939 & 15.806 & 3.006 & $*$ \\
\hline Debt/Equity ratio & 0.999 & 0.978 & 0.092 & & 1.160 & 1.297 & -0.528 & \\
\hline \multicolumn{9}{|c|}{ UK } \\
\hline Firm size & 16.592 & 16.808 & -5.097 & * & 16.198 & 16.436 & -2.198 & ** \\
\hline \% Change in dividends & 0.004 & 0.003 & 3.009 & $*$ & -0.020 & -0.021 & 5.831 & $*$ \\
\hline Earnings growth & 0.127 & 0.026 & 1.672 & $* * *$ & -0.382 & 0.242 & -3.524 & * \\
\hline Market to book ratio & 2.911 & 3.228 & -3.141 & * & 2.302 & 2.260 & 0.997 & \\
\hline Price/earnings ratio & 18.123 & 19.030 & -6.604 & * & 18.880 & 18.559 & 0.614 & \\
\hline Debt/Equity ratio & 0.495 & 0.465 & 0.120 & & 0.606 & 0.555 & 0.478 & \\
\hline
\end{tabular}

* $\quad$ Significantly different from zero at the $1 \%$ level

** $\quad$ Significantly different from zero at the $5 \%$ level

*** $\quad$ Significantly different from zero at the $10 \%$ level 